Research Article

\title{
Preparation, Characterization, and Application of Metakaolin-Based Geopolymer for Removal of Methylene Blue from Aqueous Solution
}

\author{
Marouane El Alouani (D), Saliha Alehyen, Mohammed El Achouri, and M'hamed Taibi \\ Mohammed V University in Rabat, Laboratoire de Physico-chimie des Matériaux Inorganiques et Organiques (LPCMIO), \\ Ecole Normale Supérieure (ENS), Centre des Sciences des Matériaux (CSM), Rabat, Morocco \\ Correspondence should be addressed to Marouane El Alouani; ma.elalouani@gmail.com
}

Received 30 January 2019; Revised 5 April 2019; Accepted 14 April 2019; Published 28 May 2019

Guest Editor: Mohamed Zbair

Copyright ( $) 2019$ Marouane El Alouani et al. This is an open access article distributed under the Creative Commons Attribution License, which permits unrestricted use, distribution, and reproduction in any medium, provided the original work is properly cited.

\begin{abstract}
Metakaolin-based geopolymers are aluminosilicate materials that can be used as cationic dye adsorbents in aqueous system treatment. Our aim in this paper is to study the ability of geopolymer powder produced from metakaolin and alkaline activators to act as an adsorbent to remove methylene blue (MB). The solid materials were systematically analyzed by X-ray fluorescence (XRF), X-ray diffraction (XRD), Fourier-transform infrared spectrometery (FTIR), scanning electron microscopy (SEM), energy dispersive X-ray analysis (EDX), and the point of zero charge. XRF, FTIR, XRD, SEM, and EDX analyses confirmed the formation of a geopolymer composite by geopolymerization reaction. The influence of various experimental factors such as geopolymer dosage, $\mathrm{pH}$, initial dye concentration, contact time, and temperature was assessed. Adsorption isotherms were evaluated by Langmuir, Freundlich, Temkin, and Dubinin-Radushkevich isotherms. Kinetics data were studied using pseudo-first-order, pseudo-secondorder, and intraparticle diffusion models. The thermodynamic parameters, namely, Gibbs free energy $\left(\Delta G^{\circ}\right)$, enthalpy $\left(\Delta H^{\circ}\right)$, and entropy $\left(\Delta S^{\circ}\right)$, were determined. The results indicated that the maximum decolorization was found in high $\mathrm{pH}$ values. The collected isotherm data were best fitted by the Langmuir isotherm, and the maximum adsorption capacity of dye onto the geopolymer was $43.48 \mathrm{mg} / \mathrm{g}$. The experiment kinetics followed the pseudo-second-order kinetic models. The thermodynamic results demonstrated that the adsorption of the obtained material occurs spontaneously as an endothermic process. The results confirmed that the prepared adsorbent can be used for remediation of water contaminated by MB dye.
\end{abstract}

\section{Introduction}

The rapid industrial growth has led to the release of different dyes in the aquatic environment, and the treatment of effluents has become a challenging topic in environmental sciences. With the wide applications of dyes in multiple fields such as textile, leather, additives, petroleum product, paper, cotton, wool, plastic, and pharmaceutical industries, water pollution caused by the colorants is increased, which has attracted the attention of the scientific community $[1,2]$. Generally, synthetic nondegradable dyes not only pollute water resources but also affect the human health because of their toxic nature [3]. In addition, their presence in aquatic systems, even at low concentrations, reduces the penetration of light and therefore has a detrimental effect on photosynthesis [4]. Consequently, the presence of trace amounts of these micropollutants $(<1 \mathrm{ppm})$ in industrial wastewater is extremely noticeable and unwanted [5]. Among the most used industrial dyes, methylene blue $(\mathrm{MB})$ is a basic dyestuff widely used in various industries such as textile dyeing, petroleum industries, and color photography. Therefore, the treatment of water contaminated by these chemicals is necessary both for the protection of the environment and for the reuse of these unconventional waters. In recent years, different techniques have been developed and tested to recover toxic substances from wastewaters before discharging into an aquatic environment, such as coagulation [6], advanced oxidation [7], photocatalytic degradation [8], ultrafiltration [9], ionexchange [10], electrochemical treatment [11], and adsorption [12-15]. Among various physicochemical processes, 
adsorption is a technique of choice due to its low cost, simple design, and reusability $[16,17]$. Different categories of natural and synthetic adsorbents were utilized for the removal of this organic material from aquatic media, such as kaolin [18], zeolite [19], activated carbon [20], mesoporous birnessite [1], natural clay [21], magnetic chitosan [22], fruit peels [23], biochar microparticles [24], silica [25], loofah sponge-based porous carbons [26], pyrophyllite [24], and $\mathrm{Fe}_{3} \mathrm{O}_{4}$ /activated montmorillonite nanocomposite [27]. Among the synthesized adsorbents mostly used to remove organic matters are geopolymers [28]. Geopolymers, firstly named by Joseph Davidovits [29], are formed by activation of aluminosilicate precursors, and these solids can be natural (kaolin, mica, andalusite, spinelle, illite, or Slag Hill) or synthetic (metakaolin, fly ash, calcined by-products, or industrial residues) activated by alkali silicate solution (typically $\mathrm{Na}$ or $\mathrm{K}$ ) at temperatures between $20^{\circ} \mathrm{C}$ and $100^{\circ} \mathrm{C}$ [30]. Corresponding to different $\mathrm{Si} / \mathrm{Al}$ ratios, the materials are composed of network structures of ( $\mathrm{Na}, \mathrm{K})$-poly(sialate) (-O-Si-O-Al-O-)n, (Na, K)poly(sialat-siloxo) (-O-Si-O-Al-O-Si-O)n, and (Na, K)poly(sialate-disiloxo) (O-Si-O-Al-O-Si-O-Si-O-) $n$ [29]. The geopolymers or inorganic polymers have also gained significant attention as efficient adsorbents with good physical and chemical properties. Recently, several studies were conducted in the interest of activation of aluminosilicate precursors characterized and tested for removal of dyestuffs and hazardous materials from aquatic environment [8, 31, 32].

In this work, a geopolymerization method was applied to synthesize the metakaolin-based geopolymer. The structural and morphological properties of the elaborated adsorbent were characterized by XRF, XRD, FTIR, and SEM analyses. The adsorption properties of the elaborated sample were studied in different experimental conditions, including adsorbent mass, $\mathrm{pH}$, contact time, initial dye solution, and temperature. The adsorption kinetics, isotherms, and thermodynamics data of the adsorption were investigated to study the batch adsorption process of the basic dye using the synthesized metakaolin-based geopolymer.

\section{Materials and Experimental Methods}

2.1. Materials and Chemicals. Kaolin was collected from Bab Mssila situated at Ribat El Kheir next to Sefrou city in the northwest of Morocco. The raw clay was subjected to calcination at temperatures of $800^{\circ} \mathrm{C}$ for $3 \mathrm{~h}$.

The industrial-grade sodium silicate powder (Honeywell Riedel-de Haën, Germany; 18 wt.\% $\mathrm{Na}_{2} \mathrm{O}, 63$ wt.\% $\mathrm{SiO}_{2}, 18 \mathrm{wt} . \%$ loss on ignition) and commercial sodium hydroxide ( $\mathrm{NaOH}$; 99\% purity) (ACS AR-grade pellets) were provided by Sigma-Aldrich. Methylene blue (MB) dye with the chemical composition $\mathrm{C}_{16} \mathrm{H}_{18} \mathrm{ClN}_{3} \mathrm{~S}$ and a $\mathrm{MW}$ of $319,852 \mathrm{~g} / \mathrm{mol}$ was supplied by Sigma-Aldrich.

2.2. Geopolymer Synthesis. The geopolymer sample was synthesized in several steps. The first step was to synthesize the activator solution by initially dissolving $\mathrm{Na}_{2} \mathrm{SiO}_{3}$ powder and sodium hydroxide $\mathrm{NaOH}(12 \mathrm{M})$ at a mass ratio of 2.5 [33]. The mixture was stirred at room temperature for a period of $15 \mathrm{~min}$. The second step of the elaboration is the mixing of metakaolin with the activator solution, which was conducted using in a mixer with constant stirring at ambient temperature for $15 \mathrm{~min}$ to obtain good homogenization. Then, distilled water was added at a ratio water/metakaolin of 0.34 to obtain the desired workability of the geopolymer paste. The mixture was placed in a cylindrical mould and treated at $60^{\circ} \mathrm{C}$ for 24 hours. Finally, the matrix was sieved to particle sizes $<200 \mu \mathrm{m}$ and stored in a desiccator for characterization and investigation of the adsorption tests. The mix proportions of the metakaolin-based geopolymer pastes are displayed in Table 1.

2.3. Adsorption Experiments. A series of batch adsorption experiments were carried out under different operating conditions related to adsorbent mass (0.05-0.35 g), contact time (0-220 min), initial solution $\mathrm{pH}(2-13)$, initial dye concentration $(5-60 \mathrm{mg} / \mathrm{L})$, and temperature $\left(20-70^{\circ} \mathrm{C}\right)$, at a constant agitation speed $(250 \mathrm{rpm})$ (Table 2$)$. The solution $\mathrm{pH}$ was adjusted to optimum values using $0.1 \mathrm{M} \mathrm{NaOH}$ or $0.1 \mathrm{M} \mathrm{HCl}$. Afterwards, the sample was centrifuged at $2500 \mathrm{rpm}$ for $10 \mathrm{~min}$. The initial and the residual concentrations of $\mathrm{MB}$ were measured using a spectrophotometer at a wavelength of $664 \mathrm{~nm}$. The removal efficiency of the metakaolin-based geopolymer was calculated using equation (1), adsorption capacity at any time $q_{\mathrm{t}}\left(\mathrm{mg} \cdot \mathrm{g}^{-1}\right)$ was obtained using equation (2), and adsorption capacity at equilibrium $q_{\mathrm{e}}$ $\left(\mathrm{mg} \cdot \mathrm{g}^{-1}\right)$ was determined using equation (3):

$$
\begin{aligned}
\% \text { removal } & =\frac{\left(C_{i}-C_{t}\right)}{C_{i}} \times 100, \\
q_{\mathrm{t}} & =\frac{\left(C_{\mathrm{i}}-C_{\mathrm{t}}\right)}{m} V, \\
q_{\mathrm{e}} & =\frac{\left(C_{\mathrm{i}}-C_{\mathrm{e}}\right)}{m} V,
\end{aligned}
$$

where $C_{\mathrm{i}}\left(\mathrm{mg} \cdot \mathrm{L}^{-1}\right)$ is the initial concentration of $\mathrm{MB}$ solution, $C_{\mathrm{e}}\left(\mathrm{mg} \cdot \mathrm{L}^{-1}\right)$ and $C_{\mathrm{t}}\left(\mathrm{mg} \cdot \mathrm{L}^{-1}\right)$ are, respectively, the liquid-phase concentration of $\mathrm{MB}$ at initial time and at any time $t$ after the adsorption process, $m(\mathrm{~g})$ is the weight of geopolymer, and $V(\mathrm{~L})$ is the volume of the $\mathrm{MB}$ solution.

2.4. Instrument Analysis. The chemical compositions of materials and the prepared adsorbent were determined by $\mathrm{X}$-ray fluorescence using a spectrometer dispersion wavelength-type Axios. The crystalline phases of the sample were detected using an X-ray diffractometer (Philips model 1840 equipment). The functional groups of samples were detected using Fourier-transform infrared spectrometry bruker platinum ATR apparatus, in the range of 4000$400 \mathrm{~cm}^{-1}$ wavelengths. The microstructure of metakaolin and metakaolin-based geopolymer was observed using the JEOL-6300F field-scanning electron microscope (SEM/ EDX). The concentration of $\mathrm{MB}$ was determined using the spectrophotometer JASCO V-630 UV/VIS. A pH-meter model (M 210) was used for $\mathrm{pH}$ measurement. 
TABLE 1: Chemical formulation of geopolymer.

\begin{tabular}{|c|c|c|c|c|c|c|c|c|c|}
\hline $\begin{array}{l}\text { Mixture of } \\
\text { geopolymer }\end{array}$ & $\begin{array}{c}\text { Metakaolin } \\
\text { (g) }\end{array}$ & $\begin{array}{l}\mathrm{NaOH} \\
(\mathrm{g})\end{array}$ & $\begin{array}{l}\text { Silicate } \\
\text { (g) }\end{array}$ & $\begin{array}{l}\text { Mass of water of } \\
\mathrm{NaOH} \text { dilution }(\mathrm{g})\end{array}$ & $\begin{array}{c}\text { Extra } \\
\text { water }(\mathrm{g})\end{array}$ & $\begin{array}{c}\text { Total } \\
\text { water } \\
(\mathrm{g})\end{array}$ & $\begin{array}{l}\text { Ratio water/ } \\
\text { metakaolin }\end{array}$ & $\begin{array}{l}\text { Ratio metakaolin/ } \\
\text { alkaline activator }\end{array}$ & $\begin{array}{c}\text { Ratio } \\
\mathrm{Na}_{2} \mathrm{SiO}_{3} / \\
\mathrm{NaOH}\end{array}$ \\
\hline $\begin{array}{l}\text { Mass } \\
\text { ratio (g) }\end{array}$ & 50 & 5.715 & 14.285 & 11.905 & 5 & 16.905 & 0.34 & 2.5 & 2.5 \\
\hline
\end{tabular}

TABLE 2: Experimental conditions for the adsorption of $\mathrm{MB}$ on geopolymer.

\begin{tabular}{|c|c|c|c|c|c|}
\hline Investigated parameter & Temperature $\left({ }^{\circ} \mathrm{C}\right)$ & $\mathrm{pH}$ & Geopolymer dosage (g) & Contact time $(\mathrm{min})$ & Initial concentration $(\mathrm{mg} / \mathrm{L})$ \\
\hline Geopolymer dosage (g) & 25 & 5 & $\begin{array}{c}0.05 \\
0.1 \\
0.15 \\
0.2 \\
0.25 \\
0.3 \\
0.35 \\
\end{array}$ & 120 & 40 \\
\hline Contact time $(\mathrm{min})$ & 25 & 5 & 0.1 & $\begin{array}{c}0 \\
30 \\
60 \\
90 \\
120 \\
150 \\
180 \\
220 \\
\end{array}$ & $20,30,40$ \\
\hline $\mathrm{pH}$ & 25 & $\begin{array}{c}2.21 \\
4.46 \\
6.16 \\
8.09 \\
10.06 \\
12.06 \\
\end{array}$ & 0.1 & 120 & 40 \\
\hline Temperature $\left({ }^{\circ} \mathrm{C}\right)$ & $\begin{array}{l}20 \\
50 \\
70 \\
\end{array}$ & 5 & 0.1 & 120 & 40 \\
\hline Initial concentration $(\mathrm{mg} / \mathrm{L})$ & 25 & 5 & 0.1 & 120 & $\begin{array}{c}5 \\
10 \\
20 \\
40 \\
60\end{array}$ \\
\hline
\end{tabular}

The $\mathrm{pH}$ at the point of zero charge $\left(\mathrm{pH}_{\mathrm{pzc}}\right)$ of the geopolymer was determined by the method described by Pawar et al. [34]. A series of $(0.01 \mathrm{M}) \mathrm{KNO}_{3}$ solution $(\mathrm{V}=100 \mathrm{~mL})$ were prepared, and the initial $\mathrm{pH}$ of $\mathrm{KNO}_{3}$ was adjusted to a given value from $\mathrm{pH} 2$ to 13 by the addition of $\mathrm{HCl}(0.1 \mathrm{M})$ or $\mathrm{NaOH}(0.1 \mathrm{M})$. To each solution, $0.1 \mathrm{~g}$ of geopolymer was added and shaken for $48 \mathrm{~h}$ with an agitation speed of $120 \mathrm{rpm}$ at room temperature. The differences between the $\mathrm{pH}$ value of the initial solution $\left(\mathrm{pH}_{\mathrm{I}}\right)$ and the final solution $\left(\mathrm{pH}_{\mathrm{F}}\right)$ were plotted as a function of $\mathrm{pH}_{\mathrm{I}}$. The point of intersection of this curve yielded the point of zero charge.

\section{Results and Discussion}

\subsection{Structural Analysis}

3.1.1. Chemical Analysis of Solids. The chemical composition of metakaolin and the synthesized sample is illustrated in
Table 3. The XRF analysis indicates that the metakaolin is basically formed by $\mathrm{SiO}_{2}, \mathrm{Al}_{2} \mathrm{O}_{3}$, and $\mathrm{Na}_{2} \mathrm{O}$. After activation of metakaolin by the alkali solution, it was found that a new inorganic material with an $\mathrm{Si} / \mathrm{Al}$ ratio of approximately 2.04 was formed, indicating the poly(sialate-siloxo) (PSS) (-Si-OAl-O-Si-O- $n$ nature of the formed material [35].

3.1.2. X-Ray Diffraction. Figure 1 shows the XRD patterns of kaolin, metakaolin, and geopolymer. The results of DRX analysis for kaolin show that the material is rich in kaolinite and quartz. After calcination, the disappearance of the peaks corresponding to kaolinite is observed, which is explained by the dehydroxylation of the water molecules that exist in the kaolinite structure in metakaolinite by heat treatment [36]. After the activation process, the crystalline phases were dissolved in the alkaline solution and the aluminosilicate phase was formed in the surface of metakaolin by geopolymerization reaction [37]. These results indicated the 
TABLE 3: Quantitative chemical composition of metakaolin and geopolymer.

\begin{tabular}{|c|c|c|c|c|c|}
\hline Oxides (wt.\%) & Metakaolin & Geopolymer & Elements (wt.\%) & Metakaolin & $\overline{\text { Geopolymer }}$ \\
\hline $\mathrm{SiO}_{2}$ & 37.6 & 31 & $\mathrm{O}$ & 46.7 & 45.6 \\
\hline $\mathrm{Al}_{2} \mathrm{O}_{3}$ & 19.6 & 13.4 & $\mathrm{Na}$ & 11 & 20.4 \\
\hline $\mathrm{Na}_{2} \mathrm{O}$ & 14.9 & 27.5 & $\mathrm{Si}$ & 17.6 & 14.5 \\
\hline $\mathrm{MgO}$ & 8.46 & 5.94 & $\mathrm{Al}$ & 10.4 & 7.08 \\
\hline $\mathrm{CaO}$ & 2.35 & 1.66 & $\mathrm{Fe}$ & 1.92 & 1.29 \\
\hline $\mathrm{Fe}_{2} \mathrm{O}_{3}$ & 2.75 & 1.85 & K & 1.32 & 0.936 \\
\hline $\mathrm{K}_{2} \mathrm{O}$ & 1.5 & 1.13 & $\mathrm{Ca}$ & 1.68 & 1.19 \\
\hline $\mathrm{SO}_{3}$ & 4.14 & 3.4 & $\mathrm{~S}$ & 1.66 & 1.36 \\
\hline Loss on ignition & 7.74 & 13.5 & $\mathrm{Mg}$ & 5.4 & 3.58 \\
\hline $\mathrm{SiO}_{3} / \mathrm{Al}_{2} \mathrm{O}_{3}$ & 1.92 & 2.31 & $\mathrm{Si} / \mathrm{Al}$ & 1.7 & 2.04 \\
\hline
\end{tabular}

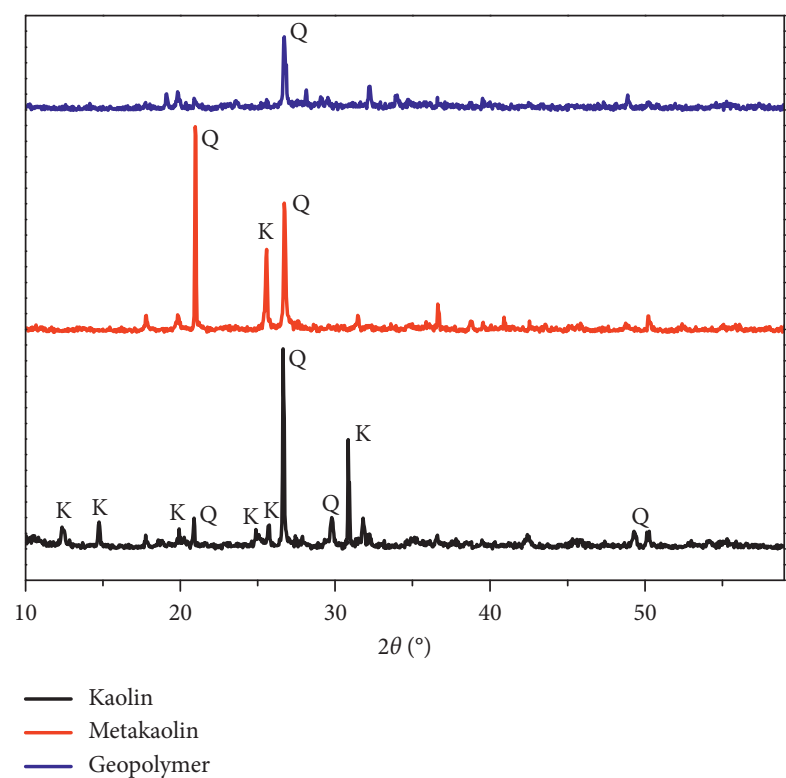

FIGURE 1: XRD patterns of kaolin, metakaolin, and geopolymer.

formation of a new product with a structure different from that of metakaolin.

3.1.3. Infrared Spectroscopy. The FTIR spectra of kaolin, metakaolin, and elaborated matrix are depicted in Figure 2, and all the band assignments are presented in Table 4. In kaolin, the bands at 3350 and $1622 \mathrm{~cm}^{-1}$ correspond to $\mathrm{OH}$ stretching and deformation of the hydroxyl group, respectively. The adsorption band appearing at $1436 \mathrm{~cm}^{-1}$ is related to the stretching vibrations of $\mathrm{O}-\mathrm{C}-\mathrm{O}$ due to atmospheric carbonation on the surface of kaolin. The band at $1151 \mathrm{~cm}^{-1}$ is due to the $\mathrm{Si}-\mathrm{O}$ outside of the plane-stretching vibration. The most intensive band at 998 was due to $\mathrm{Si}-\mathrm{O}-\mathrm{Al}$ stretching vibration. Bands which exist between $757 \mathrm{~cm}^{-1}$ and $532 \mathrm{~cm}^{-1}$ correspond to stretching vibrations of Si-O-Al. The band at $437 \mathrm{~cm}^{-1}$ is related to the $\mathrm{Si}-\mathrm{O}-\mathrm{Si}$ bending vibration. After calcination, no bands were observed between 3350 and $1622 \mathrm{~cm}^{-1}$ in metakaolin, suggesting that the thermal treatment was adequate to convert kaolin to metakaolin. The asymmetric stretching vibration of Si$\mathrm{O}-\mathrm{T}(T=\mathrm{Al}$ or $\mathrm{Si})$ at $988 \mathrm{~cm}^{-1}$ in metakaolin shifted

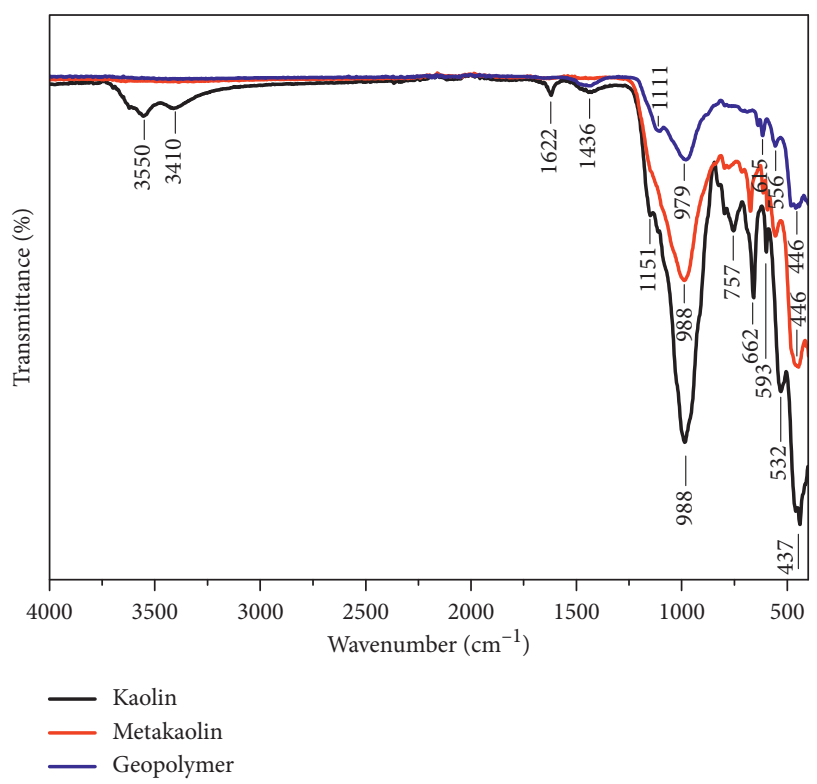

FIGURE 2: FTIR spectrum of kaolin, metakaolin, and geopolymer.

approximately $9 \mathrm{~cm}^{-1}$ after the geopolymerization reaction to $979 \mathrm{~cm}^{-1}$. The shifting and reduction of peaks in FTIR spectrum confirms the formation of a the poly(sialate-siloxo) chain in the structure by geopolymerization reaction [47].

3.1.4. Microstructural Analysis (SEM/EDX). Figure 3 shows the representative SEM images of metakaolin and the synthesized matrix. The surface morphology of metakaolin was different from that of the geopolymer matrix. SEM images (Figure 3(a)) of metakaolin showed that the sample is a heterogeneous material consisting of irregularly shaped particles. After the geopolymerization reaction (Figure 3(b)), the morphology of the geopolymer is constituted by a chain of polysilicate layers by the complete disappearance of metakaolin particles. This morphological change observed in the synthesized geopolymer is due to the dissolution of metakaolin aluminosilicates in the activator solution leading to the formation of aluminosilicate gel. EDX microanalysis was used to characterize the elemental composition of the metakaolin and geopolymer (Figure 3). According to the 
TABLE 4: FTIR bands $\left(\mathrm{cm}^{-1}\right)$ of kaolin, metakaolin, and geopolymer.

\begin{tabular}{|c|c|c|c|c|}
\hline \multicolumn{3}{|c|}{ Bands $\left(\mathrm{cm}^{-1}\right)$} & \multirow{2}{*}{ Assignments } & \multirow{2}{*}{ References } \\
\hline Kaolin & Metakaolin & Geopolymer & & \\
\hline 3550 & - & - & Stretching and deformation of $\mathrm{OH}$ & {$[38]$} \\
\hline 3410 & - & - & Stretching and deformation of $\mathrm{OH}$ & {$[34]$} \\
\hline 1622 & - & - & Stretching and deformation of $\mathrm{OH}$ & {$[34]$} \\
\hline 1436 & - & - & Stretching vibration of $\mathrm{O}-\mathrm{C}-\mathrm{O}$ & [39] \\
\hline 1151 & - & 1111 & Si-O-Si bending vibration & {$[40]$} \\
\hline 988 & 988 & 979 & Stretching vibration of $\mathrm{Si}-\mathrm{O}-\mathrm{T}(\mathrm{T}=\mathrm{Al}$ or si) & {$[41]$} \\
\hline 757 & 757 & - & Bending vibration of $\mathrm{Si}-\mathrm{O}-\mathrm{Al}$ & {$[42]$} \\
\hline 662 & 662 & 664 & Bending vibration of Si-O-Al & {$[43]$} \\
\hline 593 & 593 & - & Bending vibration of $\mathrm{Si}-\mathrm{O}-\mathrm{Al}$ & {$[44]$} \\
\hline 532 & 553 & 553 & Bending vibration of Si-O-Al & {$[45]$} \\
\hline 437 & 446 & 446 & Bending vibration of $\mathrm{Si}-\mathrm{O}-\mathrm{Si}$ & {$[46]$} \\
\hline
\end{tabular}
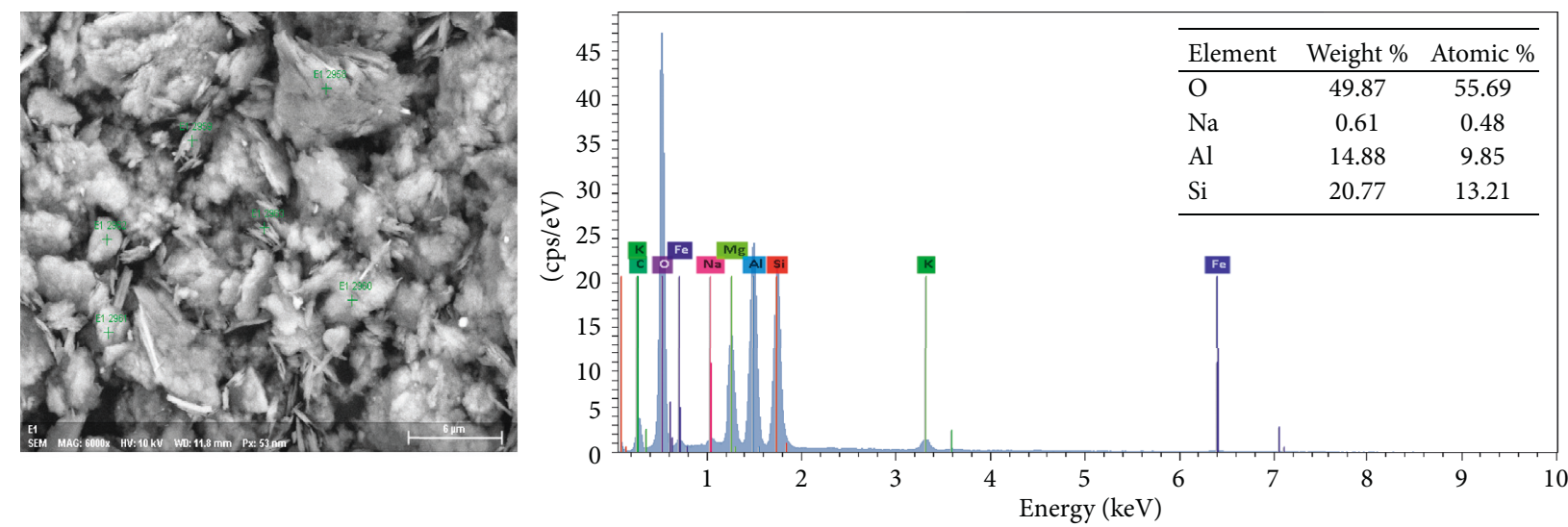

E1 2960

(a)
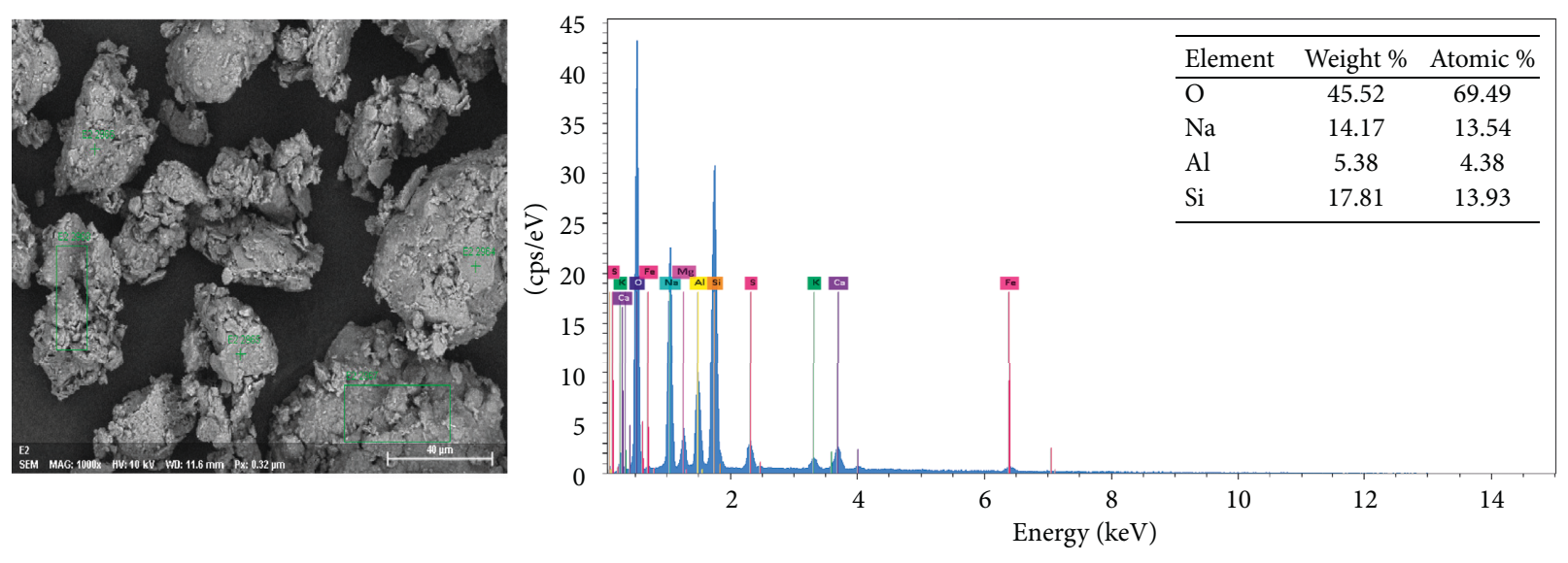

(b)

FIGURE 3: SEM micrographs and energy dispersive X-ray analysis (EDX) of metakaolin (a) and geopolymer (b).

EDX analysis (Figure 3(a)), the major elements were oxygen, silicon, and aluminum, with proportion values of $49.87,20.77$, and $14.88 \%$, respectively. The percentage of sodium elements increased from 0.61 to $14.17 \%$ (Figure 3(b)); this is due to the alkali activator used in the geopolymerization process.

\subsection{Batch Adsorption Test}

3.2.1. Effect of Adsorbent Dose. The effect of adsorbent dose on the removal of $\mathrm{MB}$ was investigated, and the results are shown in Figure 4. As can be seen, when the geopolymer mass increased from 0.05 to $0.35 \mathrm{~g} / \mathrm{L}$, the $\mathrm{MB}$ removal 


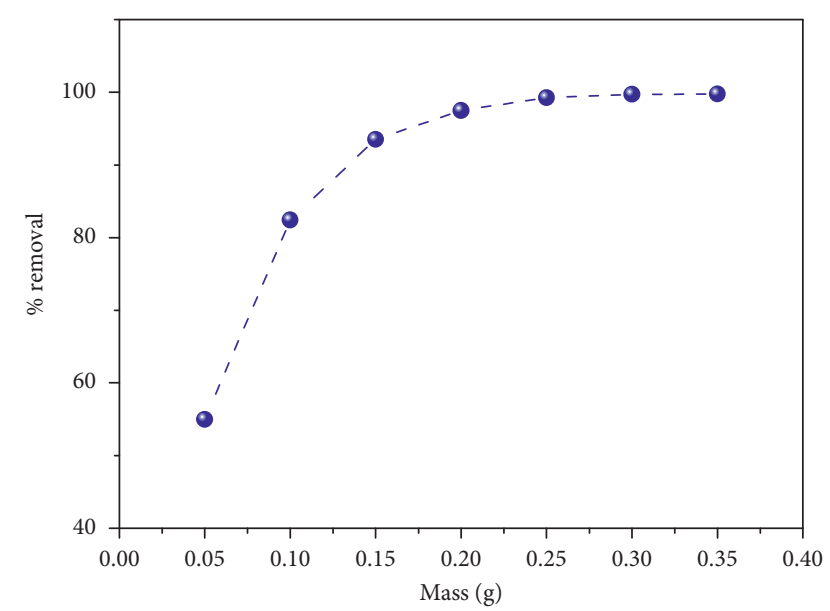

FIgURE 4: Effect of adsorbent dose on the removal efficiency.

efficiency increased from $55 \%$ to $99.77 \%$. This result might attribute to the increasing number of binding sites in the geopolymer for $\mathrm{MB}$ removal by increasing the quantity of adsorbents [48]. A similar trend was obtained for this toxic dye removal on the geopolymer paste [49] and phosphoric acid-based geopolymers [50]. Optimizing the mass of the adsorbent is a very important parameter for controlling the adsorption capacity. According to the experimental results, the adsorption assays should be performed using $0.1 \mathrm{~g} /$ $100 \mathrm{~mL}$ for $\mathrm{MB}$.

3.2.2. Effect of $p H$ on the Removal Efficiency and $p H$ Point of Zero Charge $\left(\mathrm{pH}_{\mathrm{pzc}}\right)$ of Geopolymer. The influence of $\mathrm{pH}$ is an important factor for removal of organic matter from water. Figure 5(a) represents the effect of the solution's initial $\mathrm{pH}$ in the adsorption process. It is observed that the removal efficiency increases with the rise in the $\mathrm{pH}$ value and reaches $91.2 \%$ at a $\mathrm{pH}$ value of 12.06 . The removal is affected by the change in the $\mathrm{pH}$ value of the solution. In acidic medium, the surface of the geopolymer is surrounded by $\mathrm{H}^{+}$ ions, which decrease the interaction of the solute ions $\left(\mathrm{MB}^{+}\right)$ with the sites of the geopolymeric material. On the contrary, in the basic medium, the concentration of $\mathrm{H}^{+}$ions decreases and generates a good interaction between the dye ions and the sites of the surface. Similar adsorption behaviors of MB were reported by several investigations $[20,51]$. In order to confirm this result, it is necessary to determine the $\mathrm{pH}_{\mathrm{pzc}}$ of the adsorbent. The zero point of charge (PZC) is defined as the number of positive charges equal to the number of negative charges that exist on the surface of the adsorbent. The $\mathrm{pH}_{\mathrm{PZC}}$ of the geopolymer is shown in Figure 5(b) and the $\mathrm{pH}_{\mathrm{PZC}}$ value of the adsorbent was found almost to be 9 . Thus, at $\mathrm{pH}<9$, the surface of the geopolymer is positively charged and becomes negatively charged at $\mathrm{pH}>9$. Therefore, with increasing $\mathrm{pH}$ above $\mathrm{pH}_{\mathrm{pzc}}=9$, the removal of cationic dye by the geopolymer increased slightly. The removal increase can be explained by electrostatic attraction between the particles of the geopolymer, which is negatively charged, and the cationic dye, which is positively charged [52]. These results show that the attraction between the

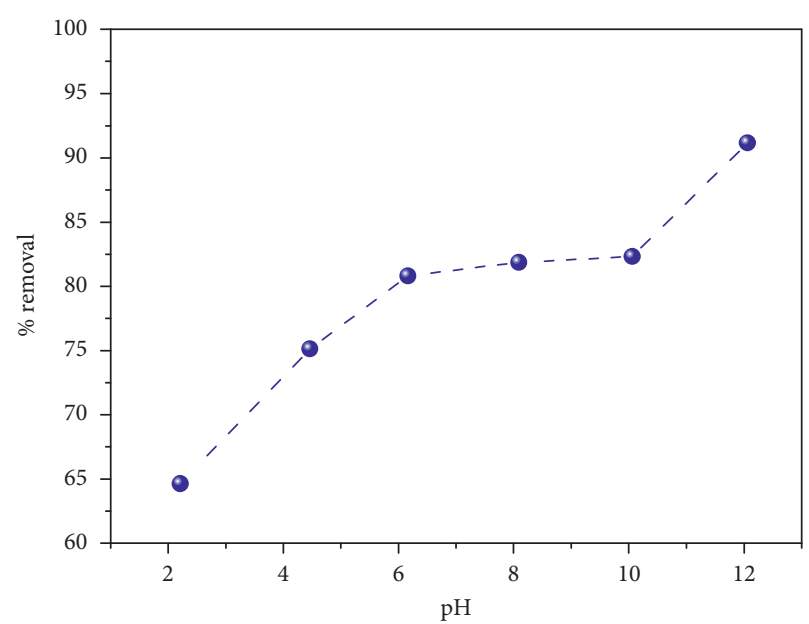

(a)

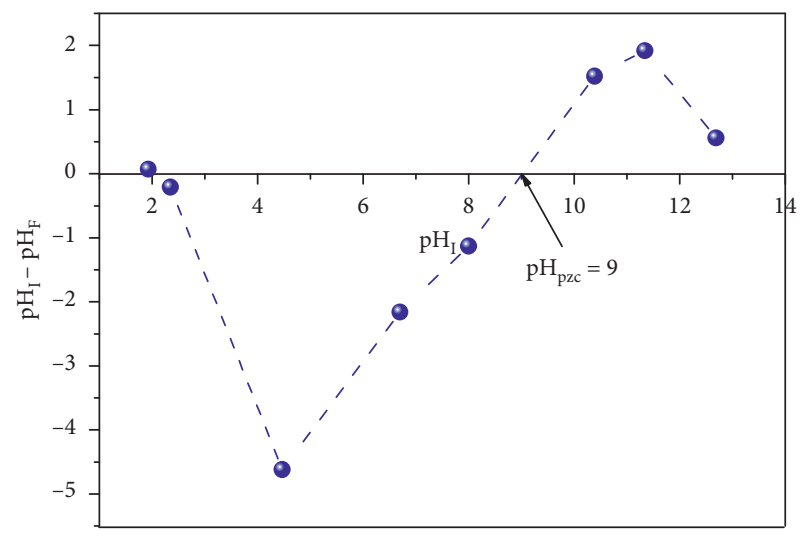

(b)

FIgURE 5: Effect of $\mathrm{pH}$ on adsorption of $\mathrm{MB}$ onto geopolymer (a) and point of zero charge $\left(\mathrm{pH}_{\mathrm{pzc}}\right)$ of geopolymer (b).

inorganic framework (negatively charged) and the methylene blue (positively charged) depends on $\mathrm{pH}$.

\subsubsection{Effect of Contact Time and Kinetics}

(1) Effect of Contact Time. The effect of contact time on the removal of MB by the geopolymer is shown in Figure 6. The results demonstrate that the removal percentage of $\mathrm{MB}$ is rapid in the first $30 \mathrm{~min}$ of contact time. Afterwards, the equilibrium time is reached within 180,180 , and $150 \mathrm{~min}$ for 20,30 , and $40 \mathrm{mg} / \mathrm{L}$, respectively. After the equilibrium, no significant change in the removal percentage of the geopolymer was observed in the different dye concentration. It was observed that for an increased contact time from 30 to $240 \mathrm{~min}$, the efficiency augmented from 87.50 to $100 \%$, 90 to $99 \%$, and 87.50 to $97.90 \%$ for concentrations of 20,30 , and $40 \mathrm{mg} / \mathrm{L}$, respectively. It can be seen that the decrease of MB removal with increasing initial $\mathrm{MB}$ concentration is due to the saturation of the adsorbent surface at high dye concentrations. Similar result was reported by Hamid et al. [53].

(2) Kinetics Studies. There are several mathematical models used to describe the adsorption kinetics of pollutants onto the adsorbent material. In this study, three kinetic models 


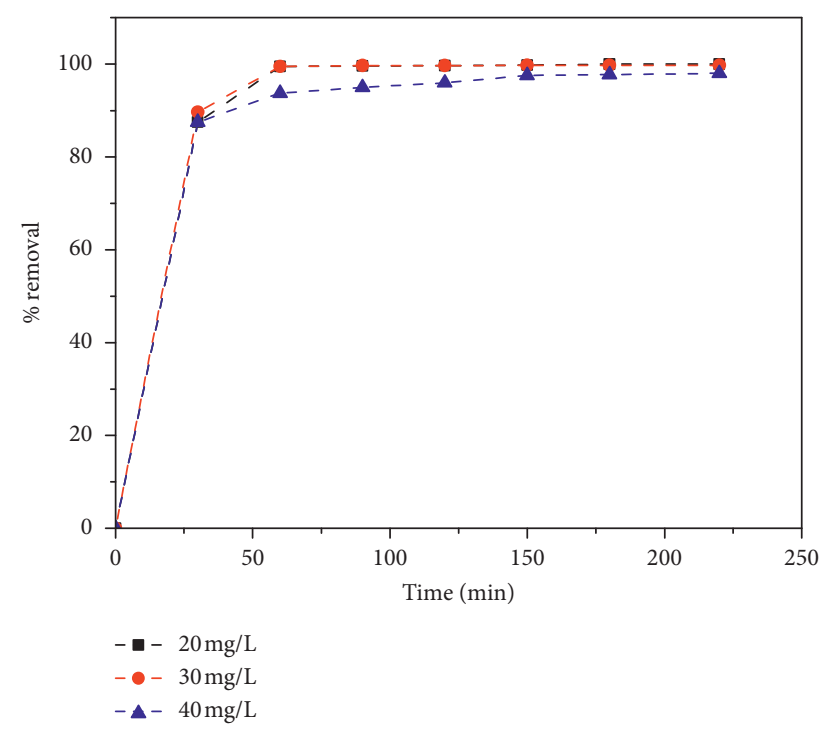

Figure 6: Effect of contact time on adsorption of $\mathrm{MB}$ onto geopolymer.

(pseudo-first-order, pseudo-second-order, and intraparticle diffusion) were applied for the adsorption of $\mathrm{MB}$ by the geopolymer to describe the adsorption process.

The pseudo-first-order model [54] is expressed as follows:

$$
\ln \left(q_{\mathrm{e}}-q_{\mathrm{t}}\right)=\ln q_{\mathrm{e}}-k_{1} t
$$

The pseudo-second-order model [55] is represented by the following equation:

$$
\frac{t}{q_{\mathrm{t}}}=\frac{1}{k_{2} q_{\mathrm{e}}^{2}}+\frac{t}{q_{\mathrm{e}}}
$$

The intraparticle diffusion model [56] is given by the following equation:

$$
q_{\mathrm{t}}=k_{\mathrm{I}} t^{1 / 2}+I
$$

where $q_{\mathrm{e}}(\mathrm{mg} / \mathrm{g})$ is the adsorption capacity at equilibrium, $q_{\mathrm{t}}(\mathrm{mg} / \mathrm{g})$ is the adsorbed concentration of $\mathrm{MB}$ at time $t, \mathrm{k}_{1}$ $(1 / \mathrm{min})$ is the pseudo-first-order rate constant for the adsorption process, $k_{2}(\mathrm{~g} / \mathrm{mg} \cdot \mathrm{min})$ is the pseudo-secondorder rate constant for the adsorption process, $k_{\mathrm{I}}(\mathrm{mg} /$ $\left.\left(\mathrm{g} \cdot \mathrm{min}^{0.5}\right)\right)$ is the intraparticle diffusion rate constant, and I $(\mathrm{mg} / \mathrm{g})$ is the intercept.

The fitting results are shown in Figures 7(a)-7(c), and the kinetics constants and correlation coefficients calculated for pseudo-first-order, pseudo-second-order, and intraparticlediffusion equations are listed in Table 5. These results revealed that the adsorption of $\mathrm{MB}$ on the geopolymer matrix is best described by the pseudo-second-order kinetic model with a high correlation coefficient (0.999), and the calculated $q_{\mathrm{e}(\mathrm{cal})}$ values are in agreement with experimental $q_{\mathrm{e}(\exp )}$ values at different initial MB concentrations. These results indicate that the chemical interaction process involves electron sharing and exchange between $\mathrm{MB}$ and functional groups of the geopolymer [57]. Similar results were also found in previous studies [23, 58].
The sialate geopolymer network consists of $\left(\mathrm{SiO}_{4}\right)$ and $\left(\mathrm{AlO}_{4}\right)$ groups connected by covalent bond $\mathrm{Si}-\mathrm{O}-\mathrm{Al}-$. The $\left(\mathrm{Na}^{+}\right)$cations present in the structural cavities of the pol$\mathrm{y}\left(\right.$ sialate) balance the negative charge of $\mathrm{Al}^{3+}$ in coordination (IV) [29]. During the adsorption phenomena, the removal of $\mathrm{MB}$ by the adsorbent can be explained by the interactions between the positive charge of $\left(\mathrm{MB}^{+}\right)$and the negative charge of $\mathrm{Al}$ tetrahedral (-Si-O-Al- $-\mathrm{O}-\mathrm{Si}-\mathrm{O})$ in the metakaolin-based geopolymer (Figure 8). This proposed mechanism explains the chemisorption of methylene blue by the metakaolin-based geopolymer.

\subsubsection{Effect of Initial Concentration Dye and Isotherms}

(1) Effect of Initial Concentration Dye. The effect of varying $\mathrm{MB}$ initial concentration on the adsorption capacity of $\mathrm{MB}$ by the geopolymer is shown in Figure 9. It can be seen that the adsorption capacity of $\mathrm{MB}$ increased as the initial $\mathrm{MB}$ concentration increased. Adsorption capacities of the geopolymer increase with the initial MB concentration increase due to the increase in the driving force of the concentration gradient [59]. A similar observation was reported previously for $\mathrm{MB}$ removal on mesoporous birnessite [1] and $\mathrm{Cu}-\mathrm{BTC}$ [58].

(2) Isotherm Studies. To investigate the adsorption mechanism of the distribution of adsorbate molecules between the liquid and the solid phase, four different models (Langmuir, Freundlich, Temkin, and Dubinin-Radushkevich) were employed to fit the adsorption data.

3.3. Langmuir Isotherm. Langmuir isotherm model is applied to explain the adsorption mechanism onto a homogeneous surface and calculate the monolayer adsorption capacity in the surface of the adsorbent [60]. This model is expressed by the following:

$$
\frac{C_{\mathrm{e}}}{q_{\mathrm{e}}}=\frac{1}{K_{\mathrm{L}} q_{\mathrm{m}}}+\frac{C_{\mathrm{e}}}{q_{\mathrm{m}}},
$$

where $q_{\mathrm{e}}$ is the amount of dye at equilibrium $(\mathrm{mg} / \mathrm{g}), C_{\mathrm{e}}$ is the equilibrium concentration of the pollutant $(\mathrm{mg} / \mathrm{L}), q_{\mathrm{m}}$ is the amount of monolayer adsorption capacity $(\mathrm{mg} / \mathrm{g})$, and $K_{\mathrm{L}}$ is the Langmuir constant ( $\mathrm{L} / \mathrm{mg})$.

The essential characteristic of the Langmuir isotherm can be expressed by the dimensionless constant separation factor $R_{\mathrm{L}}$ defined by following relationship:

$$
R_{\mathrm{L}}=\frac{1}{1+K_{\mathrm{L}} C_{0}}
$$

where $K_{\mathrm{L}}(\mathrm{L} / \mathrm{mg})$ is the Langmuir adsorption constant, $\mathrm{C}_{0}$ $(\mathrm{mg} / \mathrm{L})$ is the initial $\mathrm{MB}$ concentration. The $R_{\mathrm{L}}$ values classification is given in Table 6 [61].

3.4. Freundlich Isotherm. The Freundlich model is applicable to describe the multilayer adsorption process on active sites [62].

A linear form of the Freundlich model may be written as follows: 

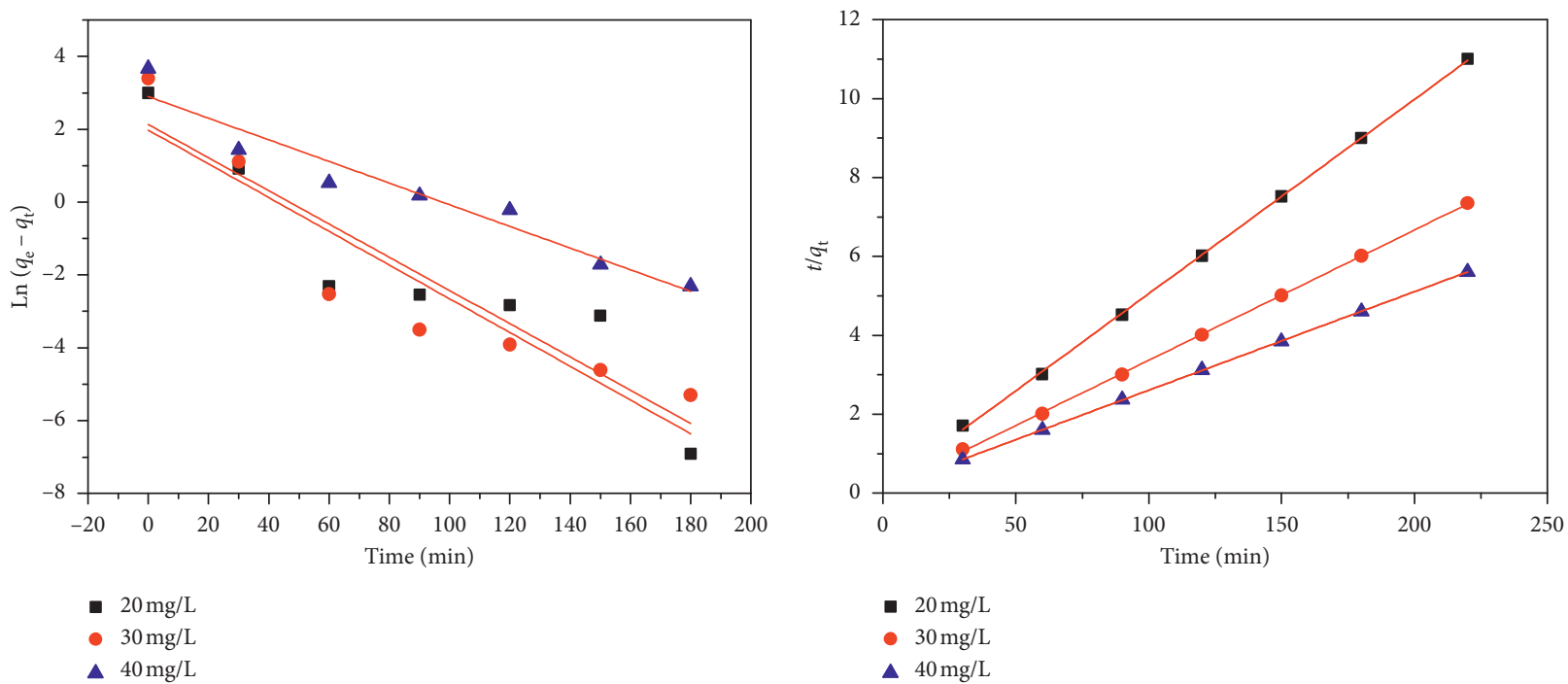

(a)

(b)

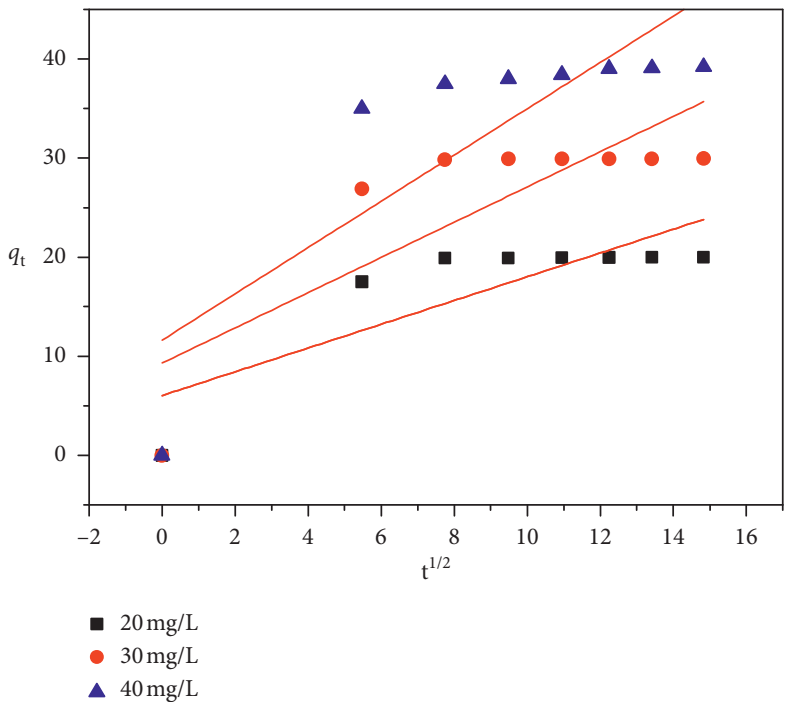

(c)

Figure 7: Pseudo-first-order (a), Pseudo-second-order (b), and Intraparticle diffusion (c) plots for adsorption of MB by geopolymer.

TABLE 5: Kinetic parameters for the adsorption of MB on geopolymer.

\begin{tabular}{|c|c|c|c|c|c|c|c|c|c|c|}
\hline \multirow{2}{*}{ Dye $C_{0}(\mathrm{mg} / \mathrm{L})$} & \multicolumn{4}{|c|}{ Pseudo-first-order } & \multicolumn{3}{|c|}{ Pseudo-second-order } & \multicolumn{3}{|c|}{ Intraparticle diffusion model } \\
\hline & $q_{\exp }$ & $q_{\mathrm{e}}(\mathrm{mg} / \mathrm{g})$ & $k_{1}(1 / \mathrm{min})$ & $R_{1}^{2}$ & $q_{\mathrm{e}}(\mathrm{mg} / \mathrm{g})$ & $k_{2}(\mathrm{~g} / \mathrm{mg} \min )$ & $R_{2}^{2}$ & $I(\mathrm{mg} / \mathrm{g})$ & $k_{\mathrm{id}}\left(\mathrm{mg} / \mathrm{g} \min ^{0.5}\right)$ & $R_{3}^{2}$ \\
\hline 20 & 19.99 & 8.43 & 0.045 & 0.875 & 20.41 & 0.031 & 0.999 & 6.042 & 1.198 & 0.683 \\
\hline 30 & 29.93 & 7.21 & 0.046 & 0.866 & 30.30 & 0.028 & 0.999 & 9.309 & 1.778 & 0.669 \\
\hline 40 & 39.2 & 18.17 & 0.029 & 0.936 & 40 & 0.0098 & 0.999 & 11.64 & 2.334 & 0.692 \\
\hline
\end{tabular}

$$
\ln q_{\mathrm{e}}=\ln K_{\mathrm{F}}+\frac{1}{n} \ln C_{\mathrm{e}}
$$

where $K_{\mathrm{F}}\left(\mathrm{mg}^{(1-n)} \mathrm{L}^{n} \mathrm{~g}^{-1}\right)$ is the adsorption capacity and $1 / n$ is the adsorption intensity.

3.5. Dubinin-Radushkevich (D-R) Isotherm. The $\mathrm{D}-\mathrm{R}$ isotherm model is a simple model applied to explain the nature of adsorption on the homogeneous or heterogeneous surface of an adsorbent and validated in high concentrations of adsorbate to determine the type of adsorption (physical or chemical) [63-65]. The simplified D-R isotherm equation is expressed as follows:

$$
\ln q_{\mathrm{e}}=\ln \left(q_{\mathrm{m}}\right)-K \varepsilon^{2},
$$

where $K$ is the D-R constant of the sorption energy $\left(\mathrm{mol}^{2} / \mathrm{kJ}^{2}\right)$ and $\varepsilon$ is the Polanyi potential which is given by 


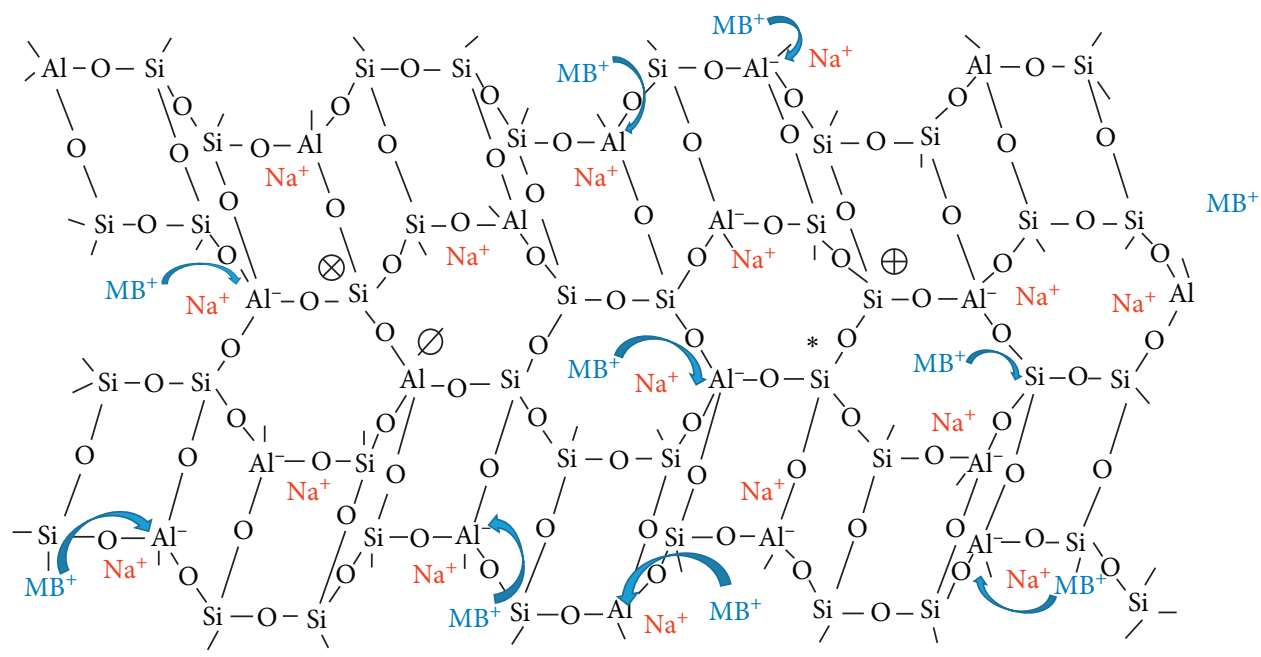

FIGURE 8: Proposed mechanism for adsorption of methylene blue by geopolymer.

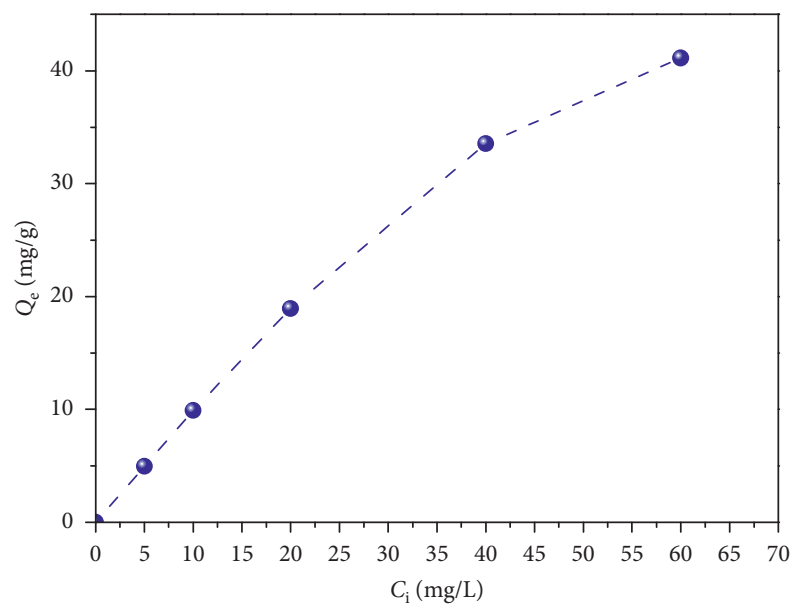

FIGURE 9: Effect of initial MB concentration on adsorption capacity of dye on geopolymer.

TABLE 6: Adsorption properties according to $\mathrm{R}_{\mathrm{L}}$ value.

\begin{tabular}{lc}
\hline$R_{\mathrm{L}}$ & Information about adsorption \\
\hline$R_{\mathrm{L}}=0$ & Irreversible \\
$0<R_{\mathrm{L}}<1$ & Favorable \\
$R_{\mathrm{L}}=1$ & Linear \\
$R_{\mathrm{L}}>1$ & Unfavorable \\
\hline
\end{tabular}

$$
\varepsilon=R T \ln \left(1+\frac{1}{C_{\mathrm{e}}}\right)
$$

where $T$ is the temperature $(\mathrm{K}), R$ is the gas constant $\left(8.314 \mathrm{~J} \cdot \mathrm{mol}^{-1} \cdot \mathrm{K}^{-1}\right), C_{\mathrm{e}}(\mathrm{mg} / \mathrm{L})$ is the equilibrium concentration of $\mathrm{MB}$ left in solution, and $q_{\mathrm{m}}$ is the $\mathrm{D}-\mathrm{R}$ maximum adsorption capacity.

The value mean energy of sorption, $E(\mathrm{~kJ} / \mathrm{mol})$, equation can be calculated from $\mathrm{D}-\mathrm{R}$ parameter $K$ as follows:

$$
E=\frac{1}{\sqrt{(2 K)}}
$$

The value of $E$ is useful for estimating the mechanism of the adsorption reaction (chemical or physical adsorption). The value of $E$ between $1 \mathrm{~kJ} / \mathrm{mol}$ and $8 \mathrm{~kJ} / \mathrm{mol}$ corresponds to physical adsorption, the $E$ value between 8 and $16 \mathrm{~kJ} / \mathrm{mol}$ corresponds to adsorption by chemisorption, and when the value of $E$ is greater than $16 \mathrm{~kJ} / \mathrm{mol}$, adsorption may be dominated by particle diffusion $[66,67]$.

3.6. Temkin Isotherm. The Temkin isotherm assumes that the sorption decreases linearly when the interaction between the surface of the adsorbent and adsorbate increases. The linear Temkin model has been used in the following form [68]:

$$
q_{\mathrm{e}}=B_{\mathrm{T}} \ln A_{\mathrm{T}}+B_{\mathrm{T}} \ln C_{\mathrm{e}},
$$

where $B_{\mathrm{T}}=R_{\mathrm{T}} / b_{\mathrm{T}}, b_{\mathrm{T}}$ is the Temkin constant related to heat of sorption (J/mol), $A_{\mathrm{T}}$ is the Temkin isotherm constant (L/ $\mathrm{g}), R$ is the universal gas constant $(8.314 \mathrm{~J} / \mathrm{mol} \cdot \mathrm{K})$, and $T$ is the temperature $(\mathrm{K})$.

Figure 10 represents the Langmuir, Freundlich, Temkin, and Dubinin-Radushkevich isotherm models. The constants calculated from the model equations (Langmuir, Freundlich, Temkin, and Dubinin-Radushkevich isotherm) are shown in Table 7. As observed, the value of $R^{2}$ obtained from the Langmuir isotherm equation (0.994) was higher than that from the Freundlich (0.963), Dubinin-Radushkevich (0.915) and Temkin (0.980) isotherm equations. These results showed that the adsorption experiments data could be well described by the Langmuir model. The adsorption occurred on the homogeneous surface as a monolayer, and the maximum monolayer adsorption capacity $\left(q_{\max }\right)$ was found to be $43.48 \mathrm{mg} / \mathrm{g}$. The $R_{\mathrm{L}}$ value was obtained within the range $0<R_{\mathrm{L}}<1$, indicating that the adsorption of cationic dye on the geopolymer material is favorable. In addition, Table 8 presents a summary of the maximum adsorption capacity $q_{\max }$ of the developed adsorbents for MB dyestuff in the aqueous medium. A comparison with other reported adsorbents showed that the $q_{\max }$ value for the geopolymer used 


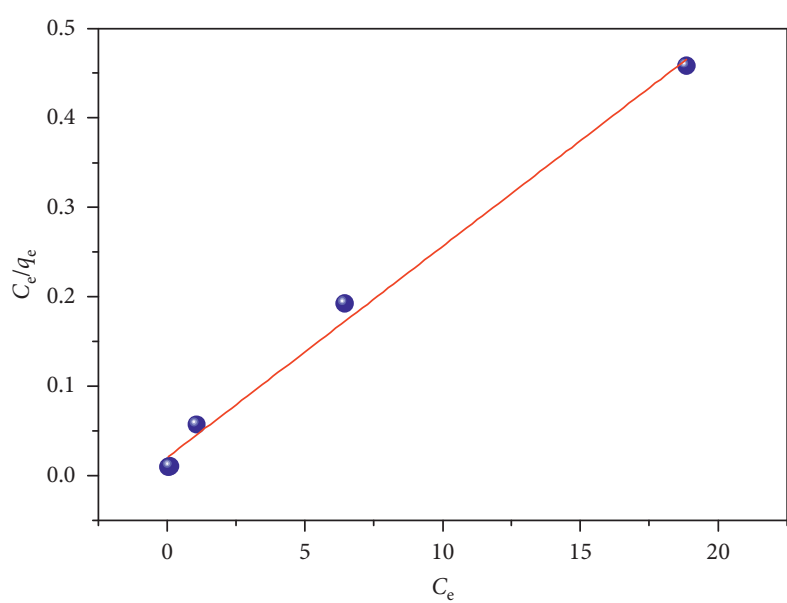

(a)

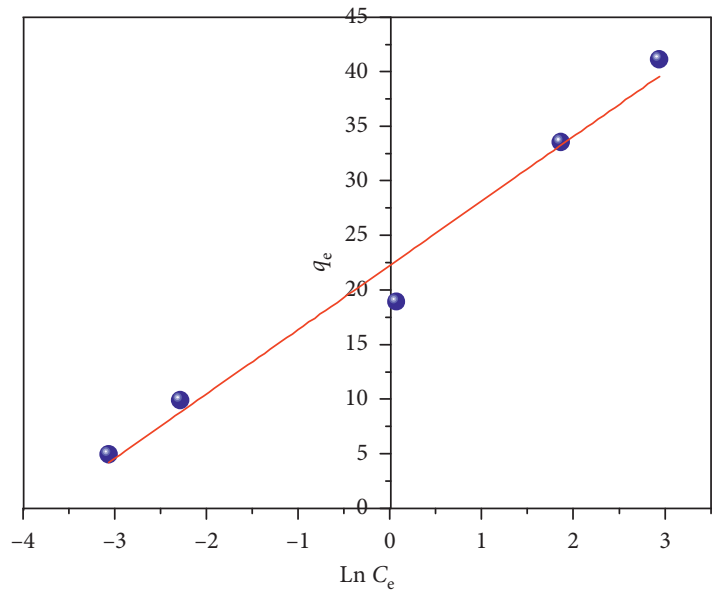

(c)

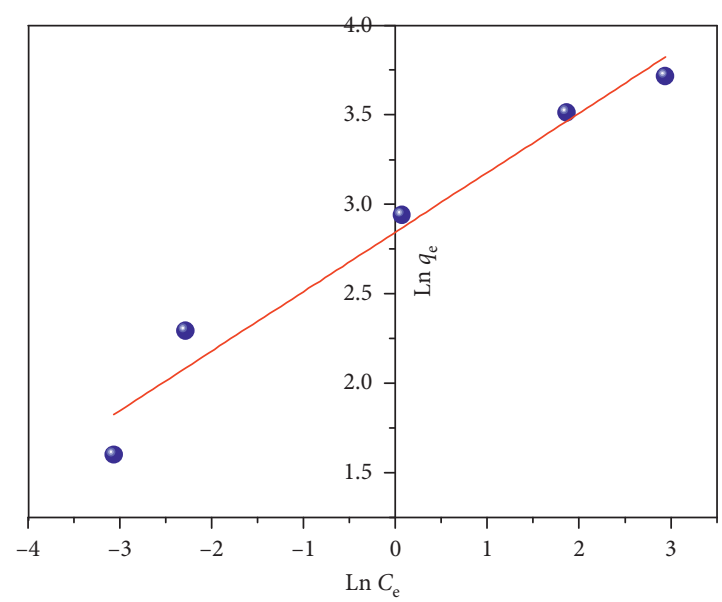

(b)

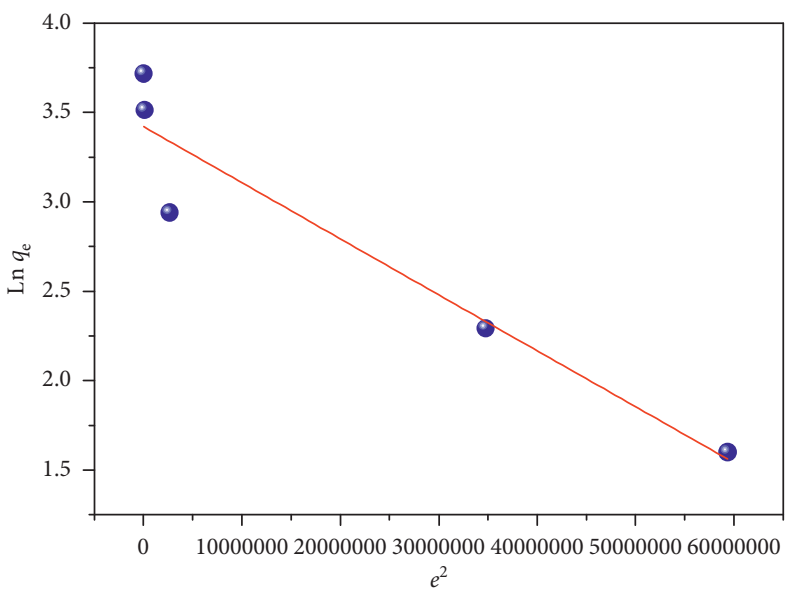

(d)

Figure 10: Langmuir (a), Freundlich (b), Temkin (c), and Dubinin-Radushkevich (d) isotherms for adsorption of MB by geopolymer.

TABLE 7: Models isotherm constants for adsorption of MB using adsorbent.

\begin{tabular}{|c|c|c|c|c|c|c|c|c|c|c|c|c|}
\hline \multicolumn{4}{|l|}{ Langmuir } & \multicolumn{3}{|c|}{ Freundlich } & \multicolumn{3}{|c|}{ Temkin } & \multicolumn{3}{|c|}{ Dubinin-Radushkevich } \\
\hline$Q_{m}(\mathrm{mg} / \mathrm{g})$ & $K_{\mathrm{L}}(\mathrm{L} / \mathrm{mg})$ & $R^{2}$ & Range $R_{\mathrm{L}}$ & $K_{\mathrm{F}}\left(\mathrm{mg}^{(1-n)} \mathrm{L}^{n} / \mathrm{g}\right)$ & $1 / n$ & $R^{2}$ & $A_{\mathrm{T}}(\mathrm{L} / \mathrm{g})$ & $B_{\mathrm{T}}$ & $R^{2}$ & $Q_{m}(\mathrm{mg} / \mathrm{g})$ & $R^{2}$ & $\mathrm{E}(\mathrm{KJ} / \mathrm{mol})$ \\
\hline 43.48 & 1.15 & 0.994 & $0.014-0.15$ & 17.18 & 0.332 & 0.963 & 43.38 & 5.897 & 0.980 & 30.57 & 0.915 & 5.77 \\
\hline
\end{tabular}

TABLE 8: Comparison of the obtained adsorption capacity with the previously developed adsorbents in the literature.

\begin{tabular}{lcc}
\hline Adsorbents & $q_{\max }(\mathrm{mg} / \mathrm{g})$ & References \\
\hline Kaolin geopolymer & 25.6 & {$[69]$} \\
Phosphoric acid-based geopolymers & 4.26 & {$[50]$} \\
fly ash-derived zeolites & 12.64 & {$[70]$} \\
Cold plasma-modified kaolin & 23 & {$[71]$} \\
Coal fly ash-based geopolymer & 50.7 & {$[72]$} \\
Fly ash-based geopolymer & 37.04 & {$[73]$} \\
Biomass FA-geopolymer & 15.4 & {$[74]$} \\
NaOH-treated raw kaolin & 16.34 & {$[75]$} \\
Metakaolin-based geopolymer & 43.48 & Present work \\
\hline
\end{tabular}

in this study is the highest, indicating that this new solid is an excellent adsorbent for the treatment of water containing MB dye.
3.6.1. Thermodynamic of Adsorption. Thermodynamic parameters have an important role to evaluate the phenomenon of the adsorption process. The thermodynamic parameters, namely, free energy $\left(\Delta G^{\circ}\right)$, enthalpy $\left(\Delta H^{\circ}\right)$, and entropy $\left(\Delta S^{\circ}\right)$, for adsorption process were obtained using the following equations [76]:

$$
\begin{aligned}
\Delta G^{\circ} & =-R T \ln \frac{q_{\mathrm{e}}}{C_{\mathrm{e}}}, \\
K_{\mathrm{d}} & =\frac{q_{\mathrm{e}}}{C_{\mathrm{e}}}, \\
\ln K_{\mathrm{d}} & =\frac{\Delta S^{\circ}}{R}-\frac{\Delta H^{\circ}}{R T},
\end{aligned}
$$

where $q_{\mathrm{e}}$ is the amount of dye adsorbed per unit mass of the adsorbent at equilibrium ( $\mathrm{mg} / \mathrm{g}), C_{\mathrm{e}}$ is the equilibrium 


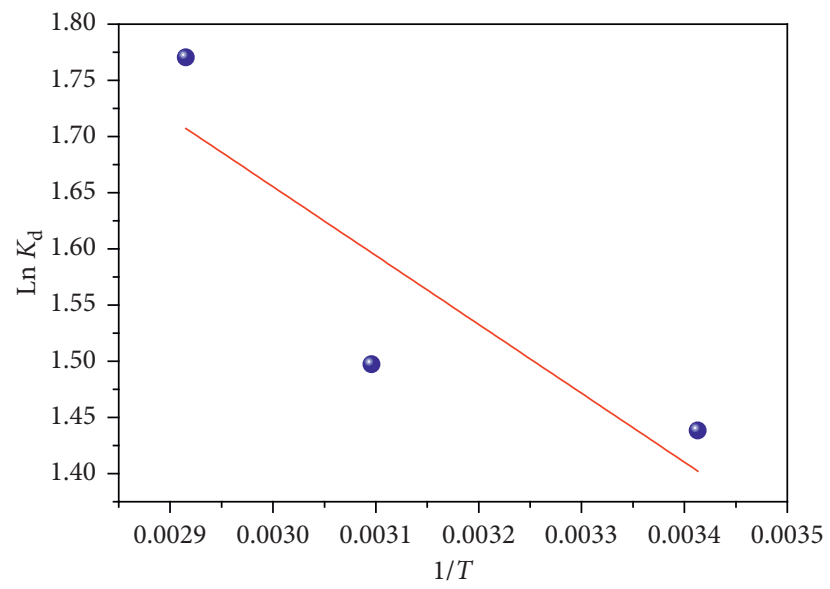

FIGURE 11: Enthalpy and entropy change determination of the adsorption of MB by geopolymer.

TABLE 9: Thermodynamic parameters for the adsorption of $\mathrm{MB}$ onto geopolymer.

\begin{tabular}{|c|c|c|c|c|c|c|}
\hline \multirow{2}{*}{ Adsorbent } & \multirow{2}{*}{ Adsorbate } & \multirow{2}{*}{$\Delta H^{\circ}\left(\mathrm{KJ} \cdot \mathrm{mol}^{-1}\right)$} & \multirow{2}{*}{$\Delta S^{\circ}\left(\mathrm{KJ} \cdot \mathrm{mol}^{-1} \cdot \mathrm{K}^{1}\right)$} & \multicolumn{3}{|c|}{$\Delta G^{\circ}\left(\mathrm{KJ} \cdot \mathrm{mol}^{-1}\right)$} \\
\hline & & & & $293 \mathrm{~K}$ & $323 \mathrm{~K}$ & $343 \mathrm{~K}$ \\
\hline Geopolymer & MB & 5.1 & 0.03 & -3.503 & -4.021 & -5.048 \\
\hline
\end{tabular}

concentration $(\mathrm{mg} / \mathrm{L}), R$ is the universal gas constant $\left(8.314 \mathrm{~J} \cdot \mathrm{mol}^{-1} \cdot \mathrm{K}^{-1}\right)$, and $T$ is the solution temperature $(\mathrm{K})$.

The values of enthalpy $\left(\Delta H^{\circ}\right)$ and entropy $\left(\Delta S^{\circ}\right)$ were calculated from the slope and intercept of the plot of $\ln K_{\mathrm{d}}$ versus $1 / T$ (Figure 11). The thermodynamic parameters for methylene blue adsorption on the composite adsorbent at various temperatures are summarized in Table 9. The positive values of entropy $\left(\Delta S^{\circ}\right)$ indicate a random increase during adsorption. The negative values of enthalpy $\Delta H^{\circ}$ indicate the endothermic nature of the process. Moreover, the values of $\Delta G^{\circ}$ determined are negative, thus confirming that the adsorption process is spontaneous and thermodynamically favorable. A similar phenomenon has been observed in the adsorption of $\mathrm{MB}$ on pomegranate peel activated carbon [77].

\section{Conclusion}

In summary, a metakaolin-based geopolymer was produced from metakaolin and alkali activators and used as an adsorbent for cationic dye removal. XRF, XRD, FTIR, and SEM studies show that a geoadsorbent was formed by the geopolymerization process. The optimum conditions of adsorption by geopolymer were found to be a geopolymer mass of $0.1 \mathrm{~g}$ in $100 \mathrm{~mL}$ of $\mathrm{MB}$, an initial concentration of $\mathrm{MB}$ $40 \mathrm{mg} / \mathrm{L}$, a contact time of $120 \mathrm{~min}$, and a basic $\mathrm{pH}$. The kinetics study of initial concentration demonstrated that adsorption equilibrium was found to follow the pseudosecond-order equation. The isotherm models data were better described by Langmuir isotherm equation with a maximum monolayer adsorption capacity of $43.48 \mathrm{mg} / \mathrm{g}$. The values of the thermodynamic parameters indicated that the adsorption was spontaneous and endothermic in nature. The overall results prove that the geopolymer has a great potential and a high selectivity and can be considered an economical adsorbent for the elimination of methylene blue from aqueous medium by batch operation.

\section{Data Availability}

The data used to support the findings of this study are available from the corresponding author upon request.

\section{Conflicts of Interest}

The authors declare that they have no conflicts of interest.

\section{References}

[1] J. Pang, F. Fu, Z. Ding, J. Lu, N. Li, and B. Tang, “Adsorption behaviors of methylene blue from aqueous solution on mesoporous birnessite," Journal of the Taiwan Institute of Chemical Engineers, vol. 77, pp. 168-176, 2017.

[2] M. Rezaei and S. Salem, "Photocatalytic activity enhancement of anatase-graphene nanocomposite for methylene removal: degradation and kinetics," Spectrochimica Acta Part A: Molecular and Biomolecular Spectroscopy, vol. 167, pp. 41-49, 2016.

[3] S. Khan and A. Malik, "Environmental and health effects of textile industry wastewater," in Environmental Deterioration and Human Health, A. Malik, E. Grohmann, and R. Akhtar, Eds., Springer, Dordrecht, Netherlands, pp. 55-71, 2014.

[4] A. Pandey, P. Singh, and L. Iyengar, "Bacterial decolorization and degradation of azo dyes," International Biodeterioration \& Biodegradation, vol. 59, no. 2, pp. 73-84, 2007.

[5] M. Rafatullah, O. Sulaiman, R. Hashim, and A. Ahmad, "Adsorption of methylene blue on low-cost adsorbents: a review," Journal of Hazardous Materials, vol. 177, no. 1-3, pp. 70-80, 2010.

[6] B. Shi, G. Li, D. Wang, C. Feng, and H. Tang, "Removal of direct dyes by coagulation: the performance of preformed polymeric aluminum species," Journal of Hazardous Materials, vol. 143, no. 1-2, pp. 567-574, 2007. 
[7] N. Nasuha, S. Ismail, and B. H. Hameed, "Activated electric arc furnace slag as an efficient and reusable heterogeneous fenton-like catalyst for the degradation of reactive black 5," Journal of the Taiwan Institute of Chemical Engineers, vol. 67, pp. 235-243, 2016.

[8] Y. Zhang and L. Liu, "Fly ash-based geopolymer as a novel photocatalyst for degradation of dye from wastewater," Particuology, vol. 11, no. 3, pp. 353-358, 2013.

[9] D. Jellouli Ennigrou, L. Gzara, M. Ramzi Ben Romdhane, and M. Dhahbi, "Cadmium removal from aqueous solutions by polyelectrolyte enhanced ultrafiltration," Desalination, vol. 246, no. 1-3, pp. 363-369, 2009.

[10] A. Da̧browski, Z. Hubicki, P. Podkościelny, and E. Robens, "Selective removal of the heavy metal ions from waters and industrial wastewaters by ion-exchange method," Chemosphere, vol. 56, no. 2, pp. 91-106, 2004.

[11] I. Sirés and E. Brillas, "Remediation of water pollution caused by pharmaceutical residues based on electrochemical separation and degradation technologies: a review," Environment International, vol. 40, pp. 212-229, 2012.

[12] M. El Alouani, S. Alehyen, M. E. Achouri, and M. Taibi, "Potential use of moroccan fly ash as low cost adsorbent for the removal of two anionic dyes (indigo carmine and acid orange)," Journal of Materials and Environmental Sciences, vol. 8, pp. 3397-3409, 2017.

[13] R. Hazzaa and M. Hussein, "Adsorption of cationic dye from aqueous solution onto activated carbon prepared from olive stones," Environmental Technology \& Innovation, vol. 4, pp. 36-51, 2015.

[14] Y. Liu, Y. Jiang, M. Hu, S. Li, and Q. Zhai, "Removal of triphenylmethane dyes by calcium carbonate-lentinan hierarchical mesoporous hybrid materials," Chemical Engineering Journal, vol. 273, pp. 371-380, 2015.

[15] M. Zbair, Z. Anfar, H. Khallok, H. A. Ahsaine, M. Ezahri, and N. Elalem, "Adsorption kinetics and surface modeling of aqueous methylene blue onto activated carbonaceous wood sawdust," Fullerenes, Nanotubes and Carbon Nanostructures, vol. 26, no. 7, pp. 433-442, 2018.

[16] Y. C. Wong, Y. S. Szeto, W. H. Cheung, and G. McKay, "Equilibrium studies for acid dye adsorption onto chitosan," Langmuir, vol. 19, no. 19, pp. 7888-7894, 2003.

[17] L. Bulgariu, L. B. Escudero, O. S. Bello et al., "The utilization of leaf-based adsorbents for dyes removal: a review," Journal of Molecular Liquids, vol. 276, pp. 728-747, 2019.

[18] K. Rida, S. Bouraoui, and S. Hadnine, "Adsorption of methylene blue from aqueous solution by kaolin and zeolite," Applied Clay Science, vol. 83-84, pp. 99-105, 2013.

[19] V. K. Gupta, R. Jain, M. N. Siddiqui et al., "Equilibrium and thermodynamic studies on the adsorption of the dye rhodamine-B onto mustard cake and activated carbon," Journal of Chemical \& Engineering Data, vol. 55, no. 11, pp. 5225-5229, 2010.

[20] H. Deng, L. Yang, G. Tao, and J. Dai, "Preparation and characterization of activated carbon from cotton stalk by microwave assisted chemical activation-application in methylene blue adsorption from aqueous solution," Journal of Hazardous Materials, vol. 166, no. 2-3, pp. 1514-1521, 2009.

[21] S. Bentahar, A. Dbik, M. E. Khomri, N. E. Messaoudi, and A. Lacherai, "Adsorption of methylene blue, crystal violet and congo red from binary and ternary systems with natural clay: kinetic, isotherm, and thermodynamic," Journal of Environmental Chemical Engineering, vol. 5, no. 6, pp. 5921-5932, 2017.
[22] W. Zhao, X. Huang, Y. Wang, S. Sun, and C. Zhao, "A recyclable and regenerable magnetic chitosan absorbent for dye uptake," Carbohydrate Polymers, vol. 150, pp. 201-208, 2016.

[23] S. Shakoor and A. Nasar, "Removal of methylene blue dye from artificially contaminated water using citrus limetta peel waste as a very low cost adsorbent," Journal of the Taiwan Institute of Chemical Engineers, vol. 66, pp. 154-163, 2016.

[24] J. Sheng, Y. Xie, and Y. Zhou, "Adsorption of methylene blue from aqueous solution on pyrophyllite," Applied Clay Science, vol. 46, no. 4, pp. 422-424, 2009.

[25] Z. Liang, Z. Zhao, T. Sun, W. Shi, and F. Cui, "Enhanced adsorption of the cationic dyes in the spherical $\mathrm{CuO} / \mathrm{meso}$ silica nano composite and impact of solution chemistry," Journal of Colloid and Interface Science, vol. 485, pp. 192-200, 2017.

[26] Z. Li, G. Wang, K. Zhai, C. He, Q. Li, and P. Guo, "Methylene blue adsorption from aqueous solution by loofah spongebased porous carbons," Colloids and Surfaces A: Physicochemical and Engineering Aspects, vol. 538, pp. 28-35, 2018.

[27] J. Chang, J. Ma, Q. Ma et al., "Adsorption of methylene blue onto $\mathrm{Fe}_{3} \mathrm{O}_{4}$ /activated montmorillonite nanocomposite," Applied Clay Science, vol. 119, pp. 132-140, 2016.

[28] A. A. Siyal, M. R. Shamsuddin, M. I. Khan et al., "A review on geopolymers as emerging materials for the adsorption of heavy metals and dyes," Journal of Environmental Management, vol. 224, pp. 327-339, 2018.

[29] J. Davidovits, "Geopolymers," Journal of Thermal Analysis, vol. 37, no. 8, pp. 1633-1656, 1991.

[30] J. Temuujin, R. P. Williams, and A. van Riessen, "Effect of mechanical activation of fly ash on the properties of geopolymer cured at ambient temperature," Journal of Materials Processing Technology, vol. 209, no. 12-13, pp. 5276-5280, 2009.

[31] T. R. Barbosa, E. L. Foletto, G. L. Dotto, and S. L. Jahn, "Preparation of mesoporous geopolymer using metakaolin and rice husk ash as synthesis precursors and its use as potential adsorbent to remove organic dye from aqueous solutions," Ceramics International, vol. 44, no. 1, pp. 416-423, 2018.

[32] Y. J. Zhang, L. C. Liu, Y. Xu, Y. C. Wang, and D. L. Xu, “A new alkali-activated steel slag-based cementitious material for photocatalytic degradation of organic pollutant from waste water," Journal of Hazardous Materials, vol. 209-210, pp. 146-150, 2012.

[33] S. Alehyen, M. Zerzouri, M. EL Alouani, M EL Achouri, and M. Taibi, "Porosity and fire resistance of fly ash based geopolymer," Journal of Materials and Environmental Sciences, vol. 9, pp. 3676-3689, 2017.

[34] R. R. Pawar, B. H. C Lalhmunsiama, H. C. Bajaj, and S.-M. Lee, "Activated bentonite as a low-cost adsorbent for the removal of $\mathrm{Cu}(\mathrm{II})$ and $\mathrm{Pb}(\mathrm{II})$ from aqueous solutions: batch and column studies," Journal of Industrial and Engineering Chemistry, vol. 34, pp. 213-223, 2016.

[35] G. S. Ryu, Y. B. Lee, K. T. Koh, and Y. S. Chung, "The mechanical properties of fly ash-based geopolymer concrete with alkaline activators," Construction and Building Materials, vol. 47, pp. 409-418, 2013.

[36] Q. Wan, F. Rao, S. Song, D. F. Cholico-González, and N. L. Ortiz, "Combination formation in the reinforcement of metakaolin geopolymers with quartz sand," Cement and Concrete Composites, vol. 80, pp. 115-122, 2017.

[37] M. Jin, Z. Zheng, Y. Sun, L. Chen, and Z. Jin, "Resistance of metakaolin-MSWI fly ash based geopolymer to acid and 
alkaline environments," Journal of Non-Crystalline Solids, vol. 450, pp. 116-122, 2016.

[38] F. G. M. Aredes, T. M. B. Campos, J. P. B. Machado, K. K. Sakane, G. P. Thim, and D. D. Brunelli, "Effect of cure temperature on the formation of metakaolinite-based geopolymer," Ceramics International, vol. 41, no. 6, pp. 73027311, 2015.

[39] J. C. Swanepoel and C. A. Strydom, "Utilisation of fly ash in a geopolymeric material," Applied Geochemistry, vol. 17, no. 8, pp. 1143-1148, 2002.

[40] A. Boukhemkhem and K. Rida, "Improvement adsorption capacity of methylene blue onto modified tamazert kaolin," Adsorption Science \& Technology, vol. 35, no. 9-10, pp. 753773, 2017.

[41] N. Belmokhtar, M. Ammari, J. Brigui, and L. Ben Allal, "Comparison of the microstructure and the compressive strength of two geopolymers derived from metakaolin and an industrial sludge," Construction and Building Materials, vol. 146, pp. 621-629, 2017.

[42] C. M. Müller, B. Pejcic, L. Esteban, C. D. Piane, M. Raven, and B. Mizaikoff, "Infrared attenuated total reflectance spectroscopy: an innovative strategy for analyzing mineral components in energy relevant systems," Scientific Reports, vol. 4, no. 1, p. $6764,2014$.

[43] T. Bakharev, "Resistance of geopolymer materials to acid attack," Cement and Concrete Research, vol. 35, no. 4, pp. 658-670, 2005.

[44] W. K. W. Lee and J. S. J. van Deventer, "The effects of inorganic salt contamination on the strength and durability of geopolymers," Colloids and Surfaces A: Physicochemical and Engineering Aspects, vol. 211, no. 2-3, pp. 115-126, 2002.

[45] İ. Kara, D. Yilmazer, and S. T. Akar, "Metakaolin based geopolymer as an effective adsorbent for adsorption of zinc(II) and nickel(II) ions from aqueous solutions," Applied Clay Science, vol. 139, pp. 54-63, 2017.

[46] D. Krizan and B. Zivanovic, "Effects of dosage and modulus of water glass on early hydration of alkali-slag cements," Cement and Concrete Research, vol. 32, no. 8, pp. 1181-1188, 2002.

[47] L. Chen, Z. Wang, Y. Wang, and J. Feng, "Preparation and properties of alkali activated metakaolin-based geopolymer," Materials, vol. 9, no. 9, p. 767, 2016.

[48] C. P. J. Isaac and A. Sivakumar, "Removal of lead and cadmium ions from water usingAnnona squamosashell: kinetic and equilibrium studies," Desalination and Water Treatment, vol. 51, no. 40-42, pp. 7700-7709, 2013.

[49] A. Maleki, M. Mohammad, Z. Emdadi, N. Asim, M. Azizi, and J. Safaei, "Adsorbent materials based on a geopolymer paste for dye removal from aqueous solutions," Arabian Journal of Chemistry, 2018, In press.

[50] M. I. Khan, T. K. Min, K. Azizli, S. Sufian, H. Ullah, and Z. Man, "Effective removal of methylene blue from water using phosphoric acid based geopolymers: synthesis, characterizations and adsorption studies," RSC Advances, vol. 5, no. 75, pp. 61410-61420, 2015.

[51] D. Kavitha and C. Namasivayam, "Experimental and kinetic studies on methylene blue adsorption by coir pith carbon," Bioresource Technology, vol. 98, no. 1, pp. 14-21, 2007.

[52] S. M. de Oliveira Brito, H. M. C. Andrade, L. F. Soares, and R. P. de Azevedo, "Brazil nut shells as a new biosorbent to remove methylene blue and indigo carmine from aqueous solutions," Journal of Hazardous Materials, vol. 174, no. 1-3, pp. 84-92, 2010.

[53] S. A. Hamid, M. Shahadat, and S. Ismail, "Development of cost effective bentonite adsorbent coating for the removal of organic pollutant," Applied Clay Science, vol. 149, pp. 79-86, 2017.

[54] S. Lagergren, "Zur theorie der sogenannten adsorption geloster stoffe," Kungliga Svenska Vetenskapsakademiens Handlingar, vol. 24, pp. 1-39, 1898.

[55] Y. S. Ho and G. McKay, "Pseudo-second order model for sorption processes," Process Biochemistry, vol. 34, no. 5, pp. 451-465, 1999.

[56] J. F. Baret, "Kinetics of adsorption from a solution. Role of the diffusion and of the adsorption-desorption antagonism," Journal of Physical Chemistry, vol. 72, no. 8, pp. 2755-2758, 1968.

[57] A. Baraka, "Adsorptive removal of tartrazine and methylene blue from wastewater using melamine-formaldehyde-tartaric acid resin (and a discussion about pseudo second order model)," Desalination and Water Treatment, vol. 44, no. 1-3, pp. 128-141, 2012.

[58] J. Hu, W. Dai, and X. Yan, "Comparison study on the adsorption performance of methylene blue and congo red on Cu-BTC," Desalination and Water Treatment, vol. 57, no. 9, pp. 4081-4089, 2016.

[59] X. Peng, D. Huang, T. Odoom-Wubah, D. Fu, J. Huang, and Q. Qin, "Adsorption of anionic and cationic dyes on ferromagnetic ordered mesoporous carbon from aqueous solution: equilibrium, thermodynamic and kinetics," Journal of Colloid and Interface Science, vol. 430, pp. 272-282, 2014.

[60] D. Singh, S. K. Singh, N. Atar, and V. Krishna, "Amino acid functionalized magnetic nanoparticles for removal of $\mathrm{Ni}(\mathrm{II})$ from aqueous solution," Journal of the Taiwan Institute of Chemical Engineers, vol. 67, pp. 148-160, 2016.

[61] T. W. Weber and R. K. Chakravorti, "Pore and solid diffusion models for fixed-bed adsorbers," AIChE Journal, vol. 20, no. 2, pp. 228-238, 1974.

[62] H. Freundlich and W. Heller, "The Adsorption ofcis- and trans-azobenzene," Journal of the American Chemical Society, vol. 61, no. 8, pp. 2228-2230, 1939.

[63] M. M. Dubinin, E. Zaverina, and L. Radushkevich, "Sorption and structure of active carbons. I. Adsorption of organic vapors," Zhurnal Fizicheskoi Khimii, vol. 21, pp. 151-162, 1947.

[64] F. Ouadjenia-Marouf, R. Marouf, J. Schott, and A. Yahiaoui, "Removal of $\mathrm{Cu}(\mathrm{II}), \mathrm{Cd}(\mathrm{II})$ and $\mathrm{Cr}(\mathrm{III})$ ions from aqueous solution by dam silt," Arabian Journal of Chemistry, vol. 6, no. 4, pp. 401-406, 2013.

[65] H. Zheng, D. Liu, Y. Zheng, S. Liang, and Z. Liu, "Sorption isotherm and kinetic modeling of aniline on Cr-bentonite," Journal of Hazardous Materials, vol. 167, no. 1-3, pp. 141-147, 2009.

[66] K. Saltalı, A. Sarı, and M. Aydın, "Removal of ammonium ion from aqueous solution by natural Turkish (Yıldizeli) zeolite for environmental quality," Journal of Hazardous Materials, vol. 141, pp. 258-263, 2007.

[67] A. Sarı, M. Tuzen, D. Citak, and M. Soylak, "Adsorption characteristics of $\mathrm{Cu}(\mathrm{II})$ and $\mathrm{Pb}(\mathrm{II})$ onto expanded perlite from aqueous solution," Journal of Hazardous Materials, vol. 148, pp. 387-394, 2007.

[68] F. Rozada, M. Otero, A. I. García, and A. Morán, “Application in fixed-bed systems of adsorbents obtained from sewage sludge and discarded tyres," Dyes and Pigments, vol. 72, no. 1, pp. 47-56, 2007.

[69] R. I. Yousef, B. El-Eswed, M. Alshaaer, F. Khalili, and H. Khoury, "The influence of using Jordanian natural zeolite on the adsorption, physical, and mechanical properties of 
geopolymers products," Journal of Hazardous Materials, vol. 165 , no. 1-3, pp. 379-387, 2009.

[70] C. D. Woolard, J. Strong, and C. R. Erasmus, "Evaluation of the use of modified coal ash as a potential sorbent for organic waste streams," Applied Geochemistry, vol. 17, no. 8, pp. 1159-1164, 2002.

[71] Ö. Yavuz and C. Saka, "Surface modification with cold plasma application on kaolin and its effects on the adsorption of methylene blue," Applied Clay Science, vol. 85, pp. 96-102, 2013.

[72] Y. Liu, C. Yan, Z. Zhang, Y. Gong, H. Wang, and X. Qiu, “A facile method for preparation of floatable and permeable fly ash-based geopolymer block," Materials Letters, vol. 185, pp. 370-373, 2016.

[73] M. EL Alouani, S. Alehyen, M. EL Achouri, and M. Taibi, "Removal of cationic dye-methylene blue-from aqueous solution by adsorption on fly ash-based geopolymer," Journal of Materials and Environmental Sciences, vol. 9, no. 1, pp. 32-46, 2018.

[74] R. M. Novais, G. Ascensão, D. M. Tobaldi, M. P. Seabra, and J. A. Labrincha, "Biomass fly ash geopolymer monoliths for effective methylene blue removal from wastewaters," Journal of Cleaner Production, vol. 171, pp. 783-794, 2018.

[75] D. Ghosh and K. G. Bhattacharyya, "Adsorption of methylene blue on kaolinite," Applied Clay Science, vol. 20, no. 6, pp. 295-300, 2002.

[76] S. A. Drweesh, N. A. Fathy, M. A. Wahba et al., "Equilibrium, kinetic and thermodynamic studies of $\mathrm{Pb}$ (II) adsorption from aqueous solutions on HCl-treated Egyptian kaolin," Journal of Environmental Chemical Engineering, vol. 4, no. 2, pp. 1674-1684, 2016.

[77] M. A. Ahmad, N. A. Ahmad Puad, and O. S. Bello, "Kinetic, equilibrium and thermodynamic studies of synthetic dye removal using pomegranate peel activated carbon prepared by microwave-induced $\mathrm{KOH}$ activation," Water Resources and Industry, vol. 6, pp. 18-35, 2014. 

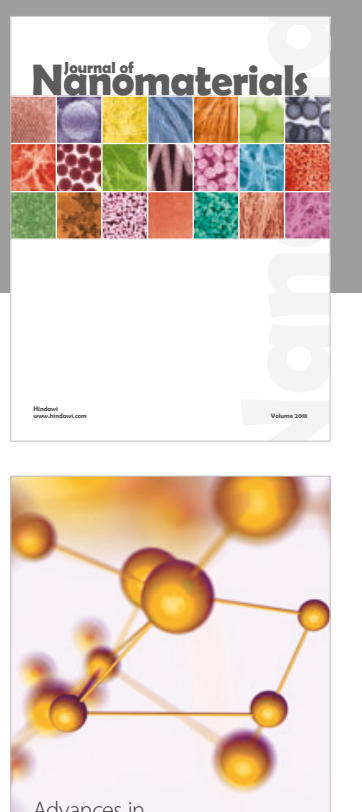

Physical Chemistry
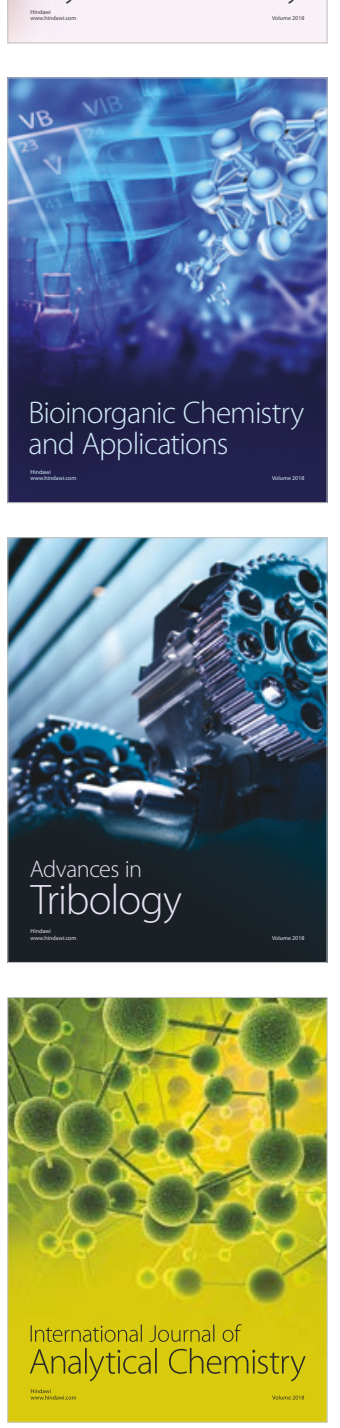

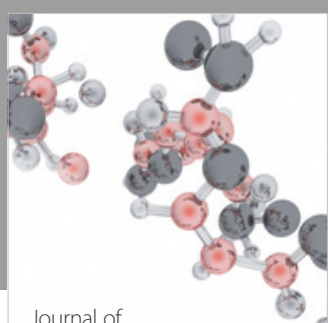

Analytical Methods

in Chemistry

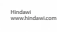

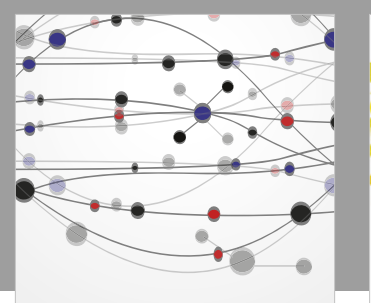

The Scientific World Journal

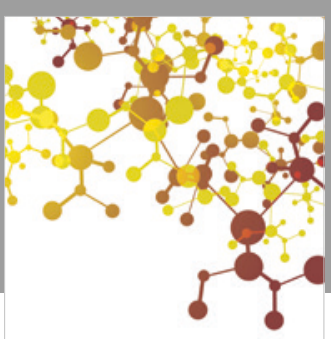

Journal of

Applied Chemistry
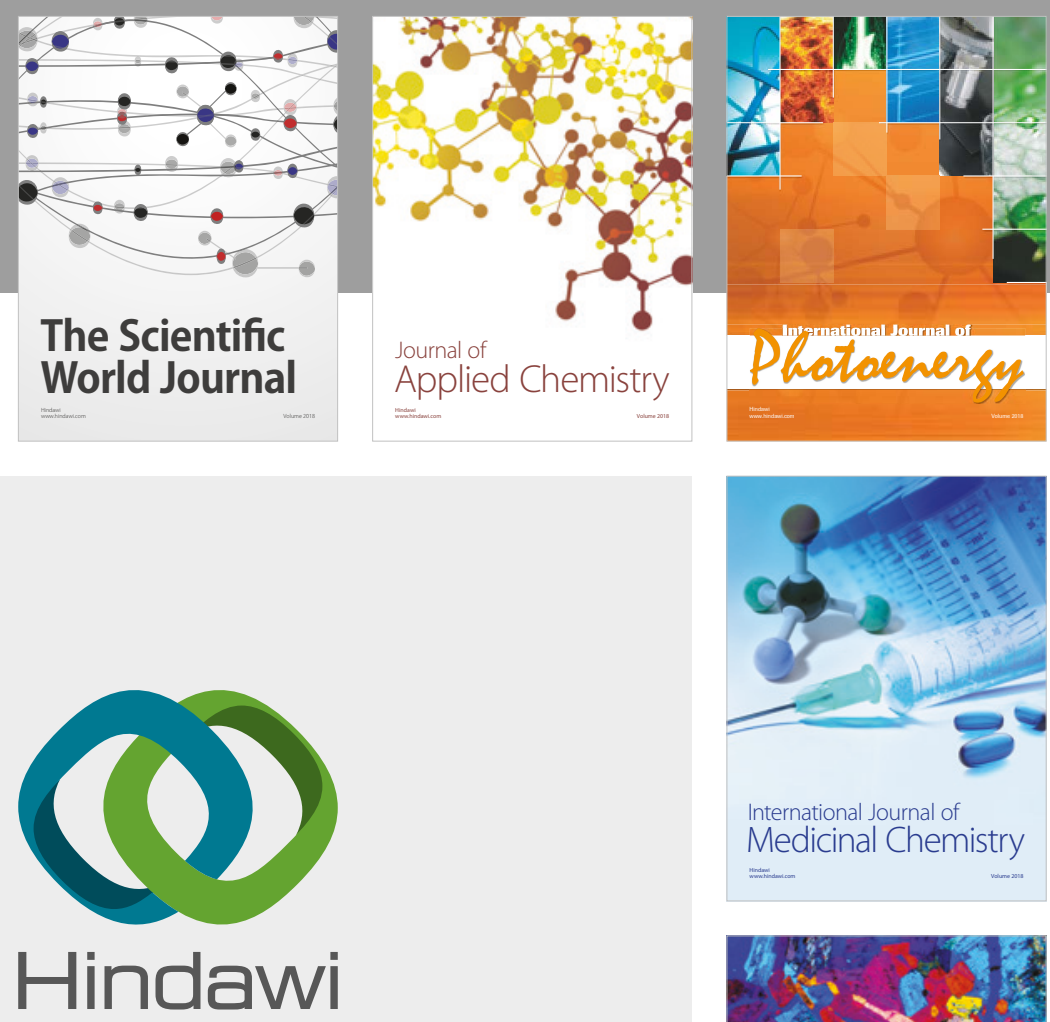

Submit your manuscripts at

www.hindawi.com
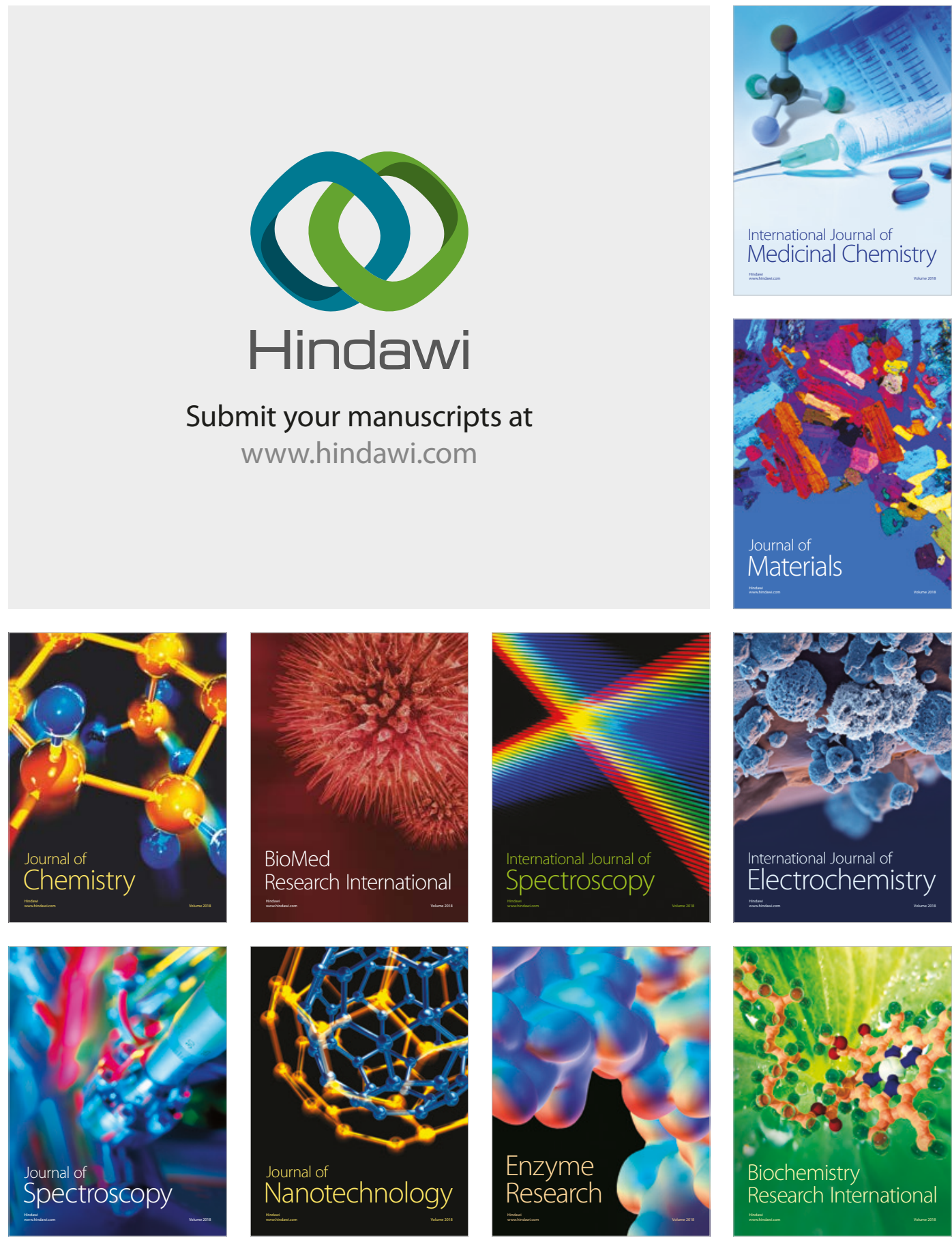
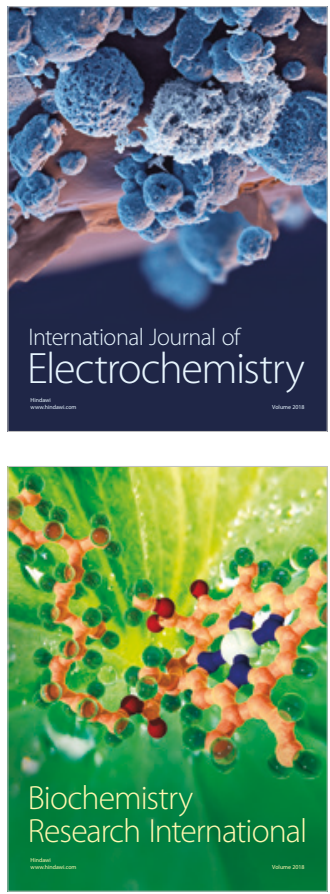